Article

\title{
Compressional-Puffing Pretreatment Enhances Neuroprotective Effects of Fucoidans from the Brown Seaweed Sargassum hemiphyllum on 6-Hydroxydopamine-Induced Apoptosis in SH-SY5Y Cells
}

\author{
Chun-Yung Huang * (i), Chia-Hung Kuo (i) and Po-Wei Chen \\ Department of Seafood Science, National Kaohsiung Marine University, No. 142, Haijhuan Rd., Nanzih District, \\ Kaohsiung 81157, Taiwan; chkuo@webmail.nkmu.edu.tw (C.-H.K.); a3989889@gmail.com (P.-W.C.) \\ * Correspondence: cyhuang@webmail.nkmu.edu.tw; Tel.: +886-7-3617141 (ext. 3606)
}

Received: 7 November 2017; Accepted: 26 December 2017; Published: 29 December 2017

\begin{abstract}
In this study, a compressional-puffing process (CPP) was used to pretreat Sargassum hemiphyllum (SH) and then fucoidan was extracted from $\mathrm{SH}$ by hot water. Three fucoidan extracts, namely SH1 (puffing at $0 \mathrm{~kg} / \mathrm{cm}^{2}$ ); SH2 (puffing at $1.7 \mathrm{~kg} / \mathrm{cm}^{2}$ ); and SH3 (puffing at $10.0 \mathrm{~kg} / \mathrm{cm}^{2}$ ) were obtained, and their compositions and biological activities were evaluated. The results indicate that CPP increased the extraction yield, total sugar content, and molar ratios of sulfate/fucose of fucoidan and decreased molecular weight and impurities of fucoidan. The SH1-SH3 extracts exhibited characteristics of fucoidan as demonstrated by the analyses of composition, FTIR spectroscopy, NMR spectroscopy, and molecular weight. All SH1-SH3 extracts showed antioxidant activities. The SH1-SH3 extracts protected SH-SY5Y cells from 6-hydroxydopamine (6-OHDA)-induced apoptosis as illustrated by cell cycle distribution, cytochrome c release, activation of caspase-8, -9 , and -3 , and DNA fragmentation analyses. Additional experiments revealed that phosphorylation of Akt is involved in the opposing effects of SH1-SH3 on 6-OHDA-induced neurotoxicity. SH3 exhibited a relatively high extraction yield, the lowest levels of impurities, and was the most effective at reversing the 6-OHDA-induced neurotoxicity of SH-SY5Y cells among SH1-SH3, which taken together indicate that it may have potential as a candidate therapeutic agent for the preventive therapy of neurodegenerative diseases.
\end{abstract}

Keywords: 6-hydroxydopamine; antioxidant; apoptosis; fucoidan; human neuroblastoma SH-SY5Y cells; neuroprotection; Sargassum hemiphyllum

\section{Introduction}

Populations worldwide are aging and as a result the prevalence of neurodegenerative diseases is increasing. These neuronal disorders are classified into two pathological classes: Movement disorders such as Parkinson's disease (PD), and cognitive deterioration and dementia, such as Alzheimer's disease (AD) [1]. PD and AD can be attributed to neuronal damage which results in loss of memory and cognition or movement disorder. The underlying mechanisms are thought to involve increased free radical damage due to oxidative stress [2]. In fact, the brain and nervous systems are susceptible to oxidative damage. A variety of evidence has demonstrated that oxidative stress-induced cell damage leads both to the physiological process of aging and to the progression of AD and PD [1]. Therefore, there is a clear need for naturally derived antioxidants that may have the potential to serve as chemopreventive agents for neurodegenerative diseases. 
Brown seaweeds contain large amounts of polysaccharides in their cell walls including fucoidans, cellulose, and alginic acids. Fucoidans are a group of fucose-containing sulfated polysaccharides (FCSPs) comprising mixtures of structurally related polysaccharides with certain variations of monosaccharide residues and containing non-carbohydrate substituents (mainly sulfate and acetyl groups) [3]. Fucoidans can be extracted from brown seaweeds such as Sargassum spp. [4]. These fucoidans have been widely documented to exhibit multiple biological functions including antioxidant, antivirus, anti-inflammatory, antitumor, and antithrombotic and anticoagulant effects $[4,5]$. However, relatively few studies on the neuroprotective effects of fucoidans from Sargassum spp. have been reported. Thus, we aimed to find extracts of fucoidan from Sargassum spp., and to study their effects on neuroprotective functions.

This study builds upon the work of our previous research [6,7]. Briefly, a brown seaweed Sargassum hemiphyllum (SH), after being washed and oven-dried, was compressional-puffed at various pressures and then the crude extracts of fucoidans were extracted by hot water. The extraction yield, composition, structure, antioxidant, and neuroprotective functions of crude extracts of fucoidan were examined. To the best of the authors' knowledge, no such studies have been reported in the literature relating to the reversal of 6-hydroxydopamine (6-OHDA)-induced apoptosis in SH-SY5Y cells by crude extracts of fucoidan extracted from compressional-puffing-pretreated SH. In addition, we explored the potential of fucoidan from $\mathrm{SH}$ to serve as natural chemopreventive agents for preventive therapy of neurodegenerative diseases, especially PD.

\section{Results and Discussion}

\subsection{Effects of Compressional-Puffing Parameters on the Degree of Moisture Loss of Puffed Algal Samples and} Extraction Yields of Fucoidan

The algal sample of SH used in this study was collected from Pingtung, Taiwan, and contained $7.05 \% \pm 0.30 \%$ protein, $1.01 \% \pm 0.01 \%$ lipid, $26.70 \% \pm 0.16 \%$ ash, and $65.24 \% \pm 0.13 \%$ carbohydrate (dry basis). The chemical composition data indicate that SH possessed a relatively high amount of carbohydrate (more than $50 \%$ ), and thus it was considered suitable for extraction of fucoidan. Before extraction of fucoidan, the algal sample was pretreated with a compressional-puffing process (CPP). The CPP has been proven to effectively increase the extraction yields of fucoidan from brown seaweeds $[6,7]$ and to augment the extraction yields of total phenolics and total flavonoids from pine needles [8,9]. Table 1 shows the operational parameters for CPP, which include mechanical compression pressure, number of compression times, puffing temperatures, and reaction time. Afterwards, the powder of $\mathrm{SH}$ (weight $2.7 \mathrm{~g}, \mathrm{H}_{2} \mathrm{O}=12.9 \%$ ) was heated and puffed at 140 and $180{ }^{\circ} \mathrm{C}$, which correspond to the pressures inside the chamber, 1.7 and $10.0 \mathrm{~kg} / \mathrm{cm}^{2}$, respectively (Table 1). CPP essentially involves three stages. In the first stage, when the temperature of the plate reaches the setting temperature, the upper plate comes down to the bottom plate. In the second stage, the upper plate applies mechanical pressure on the bottom plate three times. In the final stage, the upper plate returns to its original position which results in a sudden release of the high pressure steam, completing the process. The degree of moisture loss in the puffed algal sample is shown in Table 1 . When the pressure reached $1.7 \mathrm{~kg} / \mathrm{cm}^{2}$, the moisture loss for $\mathrm{SH} 2$ was $16.21 \% \pm 1.17 \%$. When the pressure was increased to $10.0 \mathrm{~kg} / \mathrm{cm}^{2}$, the moisture loss for SH3 was $29.56 \% \pm 2.21 \%$. Thus, the degree of moisture loss in puffed algal sample was significantly increased by elevating the puffing pressures $(p<0.05)$. We subsequently obtained fucoidans from the compressional-puffed algal samples by $85^{\circ} \mathrm{C}$ water extraction, removal of alginate and protein, 50\% ethanol precipitation, and lyophilization. Table 1 shows the extraction yields of fucoidan for SH1, SH2, and SH3, and the data were $1.51 \% \pm 0.09 \%, 1.93 \% \pm 0.28 \%$, and $2.06 \% \pm 0.14 \%$ (dry basis), respectively, by setting the puffing pressures at $0,1.7$, and $10.0 \mathrm{~kg} / \mathrm{cm}^{2}$, respectively, indicating that CPP could raise the extraction yields of fucoidan. These extraction yield data in the present study surpassed our previous findings which indicated that fucoidan extracted from compressional-puffed S. crassifolium possessed extraction yields ranging from $0.68 \%$ to $1.08 \%$ (dry 
basis) [7]. In conclusion, our data showed that CPP pretreatment effectively increased the extraction yields of fucoidan in algal samples.

Table 1. Parameters for compressional-puffing, degree of moisture loss of puffed algal samples, and extraction yields of fucoidan for $\mathrm{SH} 1, \mathrm{SH} 2$, and $\mathrm{SH} 3$.

\begin{tabular}{|c|c|c|c|c|}
\hline \multicolumn{2}{|c|}{ Variables of Compressional-Puffing } & SH1 & SH2 & SH3 \\
\hline \multirow{2}{*}{ Mechanical compression } & Pressure $\left(\mathrm{kg} / \mathrm{cm}^{2}\right)$ & 0 & 5 & 5 \\
\hline & Number of compression times & 0 & 3 & 3 \\
\hline \multirow{2}{*}{ Puffing } & Temperature $\left({ }^{\circ} \mathrm{C}\right)$ & 0 & 140 & 180 \\
\hline & Pressure $\left(\mathrm{kg} / \mathrm{cm}^{2}\right)$ & 0 & 1.7 & 10.0 \\
\hline Reaction time & Time (s) & 0 & 10 & 10 \\
\hline \multicolumn{2}{|c|}{ Degree of moisture loss of puffed algal samples } & SH1 ${ }^{1}$ & $\mathrm{SH} 2^{1}$ & $\mathrm{SH} 3^{1}$ \\
\hline \multicolumn{2}{|c|}{ Degree of moisture loss (\%) } & $0.00 \pm 0.00^{\mathrm{a}}$ & $16.21 \pm 1.17^{\mathrm{b}}$ & $29.56 \pm 2.21^{c}$ \\
\hline \multicolumn{2}{|c|}{ Variables of water extraction } & SH1 & $\mathrm{SH} 2$ & $\mathrm{SH} 3$ \\
\hline Extraction temperature & Temperature $\left({ }^{\circ} \mathrm{C}\right)$ & 85 & 85 & 85 \\
\hline Extraction time & Time (h) & 1 & 1 & 1 \\
\hline \multicolumn{2}{|c|}{ Extraction yields of fucoidan } & $\mathrm{SH} 1^{1}$ & $\mathrm{SH} 2^{1}$ & $\mathrm{SH} 3^{1}$ \\
\hline \multicolumn{2}{|c|}{ Extraction yield (\%) } & $1.51 \pm 0.09^{\mathrm{a}}$ & $1.93 \pm 0.28^{\mathrm{ab}}$ & $2.06 \pm 0.14^{b}$ \\
\hline
\end{tabular}

\subsection{Compositional and Physicochemical Analyses of Fucoidans for SH1, SH2, and SH3}

The compositional analyses of fucoidan extracts for SH1-SH3 were performed and the results are presented in Table 2. The total sugar contents for SH1, SH2, and SH3 were $53.67 \% \pm 2.59 \%$, $58.83 \% \pm 1.61 \%$, and $68.83 \% \pm 1.91 \%(w / w$, dry basis), respectively, and were upregulated by raising the puffing pressures. The total sugar contents of SH1-SH3 were comparable to the amount $(61 \%$, dry basis) of polysaccharide extracted from brown alga $S$. tenerrimum in a previous study [10]. The uronic acid contents for SH1-SH3 ranged from $5.66 \% \pm 0.08 \%$ to $7.04 \% \pm 0.22 \%$ ( $w / w$, dry basis) (Table 2), and did not appear to be related to the puffing pressures. The fucose contents for SH1-SH3 ranged from $22.76 \% \pm 0.38 \%$ to $24.53 \% \pm 1.15 \%$ ( $w / w$, dry basis) (Table 2$)$, suggesting that CPP did not obviously affect the fucose content. The sulfate content of fucoidan plays a critical role in the biological functions as previously noted by other investigators [11,12]. We thus measured the sulfate contents for $\mathrm{SH} 1, \mathrm{SH} 2$, and $\mathrm{SH} 3$ and the percentages were $18.87 \% \pm 1.65 \%, 15.58 \% \pm 0.16 \%$, and $24.16 \% \pm 2.80 \%$ ( $w / w$, dry basis), respectively (Table 2$)$, and found that $\mathrm{SH} 3$ possessed the highest sulfate content among SH1-SH3. The molar ratio of sulfate/fucose in fucoidan was shown to play a pivotal role in the bioactivities [13]. We therefore calculated the molar ratios of sulfate/fucose in SH1, SH2, and SH3 and the results were as follows: $1.32 \pm 0.11,1.17 \pm 0.01$, and $1.74 \pm 0.20$, respectively (Table 2). The trend was similar to that of sulfate content, and SH3 had the highest molar ratio of sulfate/fucose among SH1-SH3. Thus, it was expected that SH3 may have high biological activity, and further investigation was warranted. The co-extracted substances such as alginate, protein, and polyphenols can be regarded as impurities [6]. The alginate was not detected in SH1-SH3. From Table 2, the total amount of protein and polyphenol impurities of fucoidan can be calculated for SH1 $(2.28+1.25=3.53, \mathrm{~g} / 100 \mathrm{~g}$, dry basis $)$, SH2 $(2.05+1.06=3.11, \mathrm{~g} / 100 \mathrm{~g}$, dry basis $)$, and SH3 $(1.83+0.71=2.54, \mathrm{~g} / 100 \mathrm{~g}$, dry basis $)$, and the impurity contents were downregulated by elevated puffing pressures. It was found that CPP may potentially decrease the amount of impurities in extracts of fucoidan, which would be beneficial for commercial production of fucoidan with a high level of purity. Moreover, the monosaccharide compositions of SH1-SH3 were measured and the results are presented in Table 2. Fucose, galactose, and mannose were shown to be the major monosaccharides in 
SH1-SH3. Smaller amounts of glucuronic acid, rhamnose, and glucose, as well as a tiny amount of xylose were also detected. Generally, CPP did not apparently affect the monosaccharide compositions of fucoidan for SH1-SH3. The fucoidan extracts obtained by SH1-SH3 were further characterized using Fourier transform infrared (FTIR) spectroscopy, nuclear magnetic resonance (NMR) spectroscopy, and molecular weight analyses. The FTIR results of SH1-SH3 shown in Figure 1A suggest that the typical signals for sulfated polysaccharides were obtained. The signals at 3401, 2941, 1230, and $1055 \mathrm{~cm}^{-1}$ correspond to the $\mathrm{O}-\mathrm{H}$ stretching vibrations, the $\mathrm{C}-\mathrm{H}$ stretching vibrations, the $\mathrm{S}=\mathrm{O}$ asymmetric stretching vibration of the sulfate group, and the $\mathrm{C}-\mathrm{O}-\mathrm{H}$ in the glucosidal bond or $\mathrm{C}-\mathrm{O}-\mathrm{C}$ stretching vibrations in the ring [14,15]. The IR bands at 1621 and $1421 \mathrm{~cm}^{-1}$ arose from scissoring vibration of water and in-plane ring $\mathrm{CCH}, \mathrm{OCH}$ and $\mathrm{COH}$ vibrations typical for polysaccharides. These bands may have contribution from antisymmetric and symmetric vibrations of carboxylate anions $\left(\mathrm{COO}^{-}\right)$ in glucuronate units [14-16]. Bands at 900 and $837 \mathrm{~cm}^{-1}$ corresponded to $\mathrm{C} 1-\mathrm{H}$ bending vibration in $\beta$-anomeric units (probably galactose) and equatorial $\mathrm{C} 2-\mathrm{O}-\mathrm{S}$ or $\mathrm{C} 3-\mathrm{O}-\mathrm{S}$ bending vibrations in sulfate semi-esters. Other IR bands of sulfates are visible in Figure 1A near 620 and $580 \mathrm{~cm}^{-1}$. These bands were attributed to the anti-symmetric and symmetric $\mathrm{O}=\mathrm{S}=\mathrm{O}$ deformations [17]. Due to the similarity of the FTIR spectra in SH1-SH3, the structural aspects of sulfated polysaccharide and the positions of the sulfate group were not significantly altered by CPP. NMR spectroscopy is one of the most powerful techniques for analyzing the structure of complex polysaccharides [18]. In the present study, we utilized ${ }^{1} \mathrm{H}-\mathrm{NMR}$ spectra to evaluate whether the structural features among $\mathrm{SH} 1-\mathrm{SH} 3$ are different. The ${ }^{1} \mathrm{H}-\mathrm{NMR}$ spectra (Figure 1B) for SH1-SH3 revealed certain characteristic signals of fucoidan, which were in agreement with data reported by other investigators; for example, the anomeric signals at 5.5-5.0 ppm are consistent with the presence of L-fucopyranosyl units [19]. The signals at 4.57 and $4.46 \mathrm{ppm}$ may be assigned to $\mathrm{H}-2$ of a 2 -sulfated fucopyranose residue [19]. The signal at $4.13 \mathrm{ppm}(\mathrm{H}-4)$ indicates 3-linked $\alpha$-L-fucose [16]. The narrow signals at 3.9-3.6 ppm may be attributed to the presence of mannitol [20], a low-molecular metabolite of brown seaweeds [21] which may have been coextracted with our fucoidans. The detection of signals at $3.78 \mathrm{ppm}(\mathrm{H}-3)$ and $3.72 \mathrm{ppm}(\mathrm{H}-4)$ can be tentatively assigned to 4 -linked $\beta$-D-galactose and 2,3-linked $\alpha-\beta$-mannose, respectively [16]. The signals around $2.56 \mathrm{ppm}$ may be tentatively assigned to the presence of glutamate [22,23], which may exist in the forms of amino acids or proteins coextracted with our fucoidans (Table 2). Several singlets around $2.2 \mathrm{ppm}$ arose from methyl protons in $O$-acetyls $[17,24]$. These data are consistent with the findings reported by Bilan et al. (2004), which showed that algal polysaccharides are heterogeneous and branched, and certain additional constituents such as acetyl groups were also observed [24]. In addition, the signal at $1.32 \mathrm{ppm}$ indicates the C6 methyl protons of L-fucopyranose [25]. In general, certain impurities such as mannitol and proteins are co-extracted with fucoidan extracts as revealed by NMR analyses. Most importantly, due to the similarity of the ${ }^{1} \mathrm{H}-\mathrm{NMR}$ spectra in SH1-SH3 (Figure 1B), it may be concluded that the structural features of fucoidan were not obviously altered by CPP. The high-performance liquid chromatography (HPLC) gel filtration analysis was utilized to characterize the molecular weights of SH1-SH3. The data presented in Figure $1 \mathrm{C}$ revealed that the average molecular weights of extracts for SH1 were 617.04 and $523.19 \mathrm{kDa}$; for SH2, the weights were 608.80 and $518.95 \mathrm{kDa}$; and for SH3, the weights were 601.20 and $384.50 \mathrm{kDa}$, respectively. The molecular weights of SH1-SH3 were reduced by raising the puffing pressures. These results suggest that CPP might have effects on the breakdown of the fucoidan backbone if high temperature and high pressure treatments are used as $\mathrm{SH} 2$ and SH3 appeared to result in a decrease of molecular weights. Taken together, CPP had certain effects including increased total sugar content, increased molar ratios of sulfate/fucose, decreased impurities of fucoidan, and decreased molecular weight. SH1-SH3 showed characteristics of fucoidan as elucidated by compositional, FTIR spectroscopy, NMR spectroscopy, and molecular weight analyses. In addition, $\mathrm{SH} 3$ contained the highest total sugar content and molar ratio of sulfate/fucose and the smallest molecular weight among $\mathrm{SH} 1-\mathrm{SH} 3$, and thus the biological functions of $\mathrm{SH} 3$ warrant further examination. 
Table 2. Compositional analyses for $\mathrm{SH} 1, \mathrm{SH} 2$, and $\mathrm{SH} 3$.

\begin{tabular}{|c|c|c|c|}
\hline Chemical Composition & $\mathrm{SH}^{2}$ & $\mathrm{SH} 2^{2}$ & $\mathrm{SH}^{2}$ \\
\hline Total sugar $(\%)$ & $53.67 \pm 2.59^{a}$ & $58.83 \pm 1.61^{b}$ & $68.83 \pm 1.91^{c}$ \\
\hline Uronic acid (\%) & $5.66 \pm 0.08^{a}$ & $7.04 \pm 0.22^{c}$ & $6.12 \pm 0.08^{b}$ \\
\hline Fucose $(\%)$ & $24.53 \pm 1.15^{\mathrm{a}}$ & $22.76 \pm 0.38^{a}$ & $23.87 \pm 1.76^{\mathrm{a}}$ \\
\hline Sulfate $(\%)$ & $18.87 \pm 1.65^{b}$ & $15.58 \pm 0.16^{\mathrm{a}}$ & $24.16 \pm 2.80^{c}$ \\
\hline Sulfate/fucose (molar ratio) ${ }^{1}$ & $1.32 \pm 0.11^{\mathrm{a}}$ & $1.17 \pm 0.01^{\mathrm{a}}$ & $1.74 \pm 0.20^{\mathrm{b}}$ \\
\hline Protein $(\%)$ & $2.28 \pm 0.05^{c}$ & $2.05 \pm 0.12^{b}$ & $1.83 \pm 0.07^{\mathrm{a}}$ \\
\hline Polyphenols (\%) & $1.25 \pm 0.08^{c}$ & $1.06 \pm 0.06^{b}$ & $0.71 \pm 0.06^{\mathrm{a}}$ \\
\hline Monosaccharide compositions (molar ratio) & SH1 & $\mathrm{SH} 2$ & $\mathrm{SH} 3$ \\
\hline Fucose & 1.00 & 1.00 & 1.00 \\
\hline Mannose & 0.32 & 0.27 & 0.28 \\
\hline Rhamnose & 0.15 & 0.15 & 0.14 \\
\hline Glucose & 0.09 & 0.07 & 0.06 \\
\hline Glucuronic acid & 0.21 & 0.20 & 0.20 \\
\hline Galactose & 0.40 & 0.35 & 0.35 \\
\hline Xylose & $\mathrm{ND}^{3}$ & 0.02 & 0.02 \\
\hline
\end{tabular}

${ }^{1}$ Sulfate $/$ fucose (molar ratio) $=$ (weight of sulfate $/$ molecular weight of sulfate) $/$ (weight of fucose $/$ molecular weight of fucose); ${ }^{2}$ values are mean $\pm \mathrm{SD}(n=3)$; means in the same row followed by the different letters $\left(\right.$ in $^{\mathrm{a}}, \mathrm{b}$, and $\left.{ }^{\mathrm{c}}\right)$ are significantly different $(p<0.05) ;{ }^{3}$ ND: not detected.

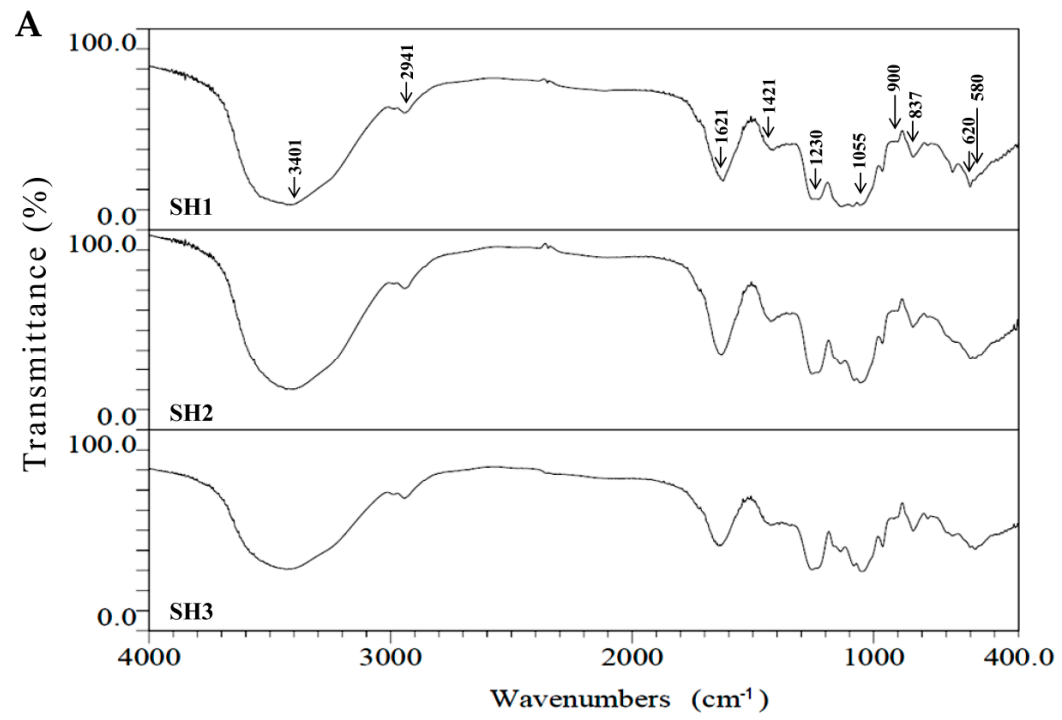

Figure 1. Cont. 


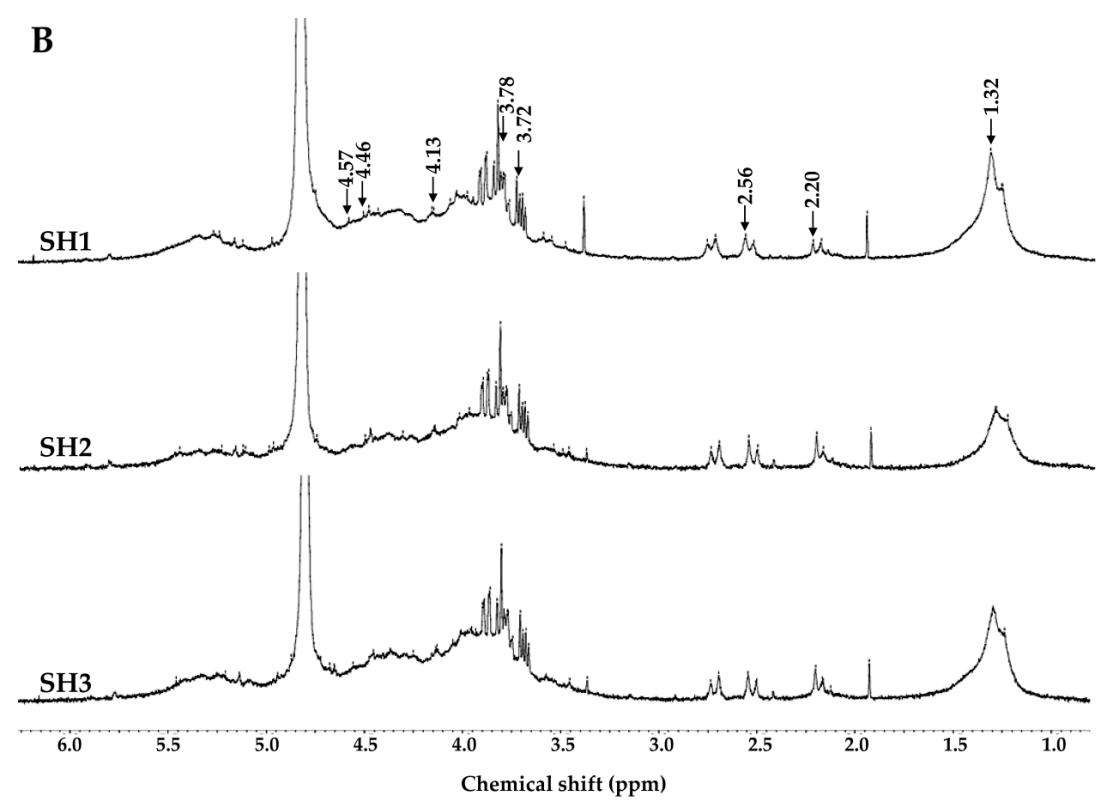

C

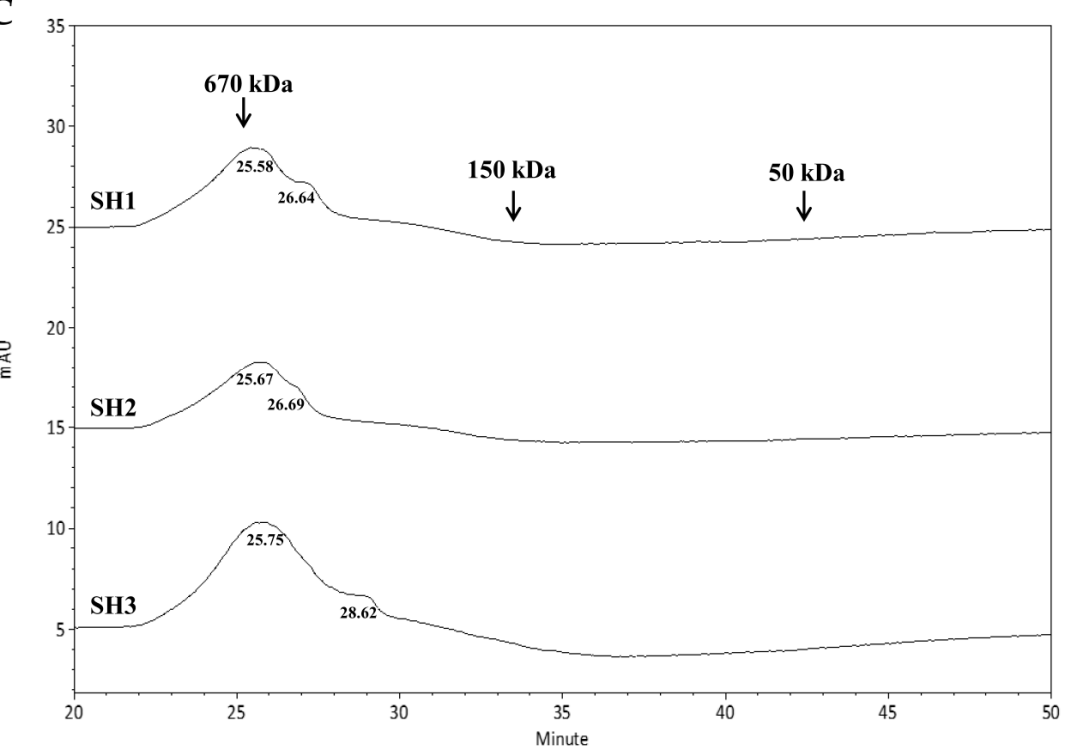

Figure 1. Characteristics of fucoidan extracts obtained from S. hemiphyllum under different compressional-puffing pretreatments. (A) FTIR spectra for SH1, SH2, and, SH3. Absorption bands at 3401, 2941, 1621, 1421, 1230, 1055, 900, 837, 620, and $580 \mathrm{~cm}^{-1}$ are indicated; (B) ${ }^{1} \mathrm{H}$-NMR spectra for SH1, SH2, and SH3. Chemical shifts at 4.57, 4.46, 4.13, 3.78, 3.72, 2.56, 2.20, and 1.32 ppm are indicated; (C) size exclusion chromatographic profiles for $\mathrm{SH} 1, \mathrm{SH} 2$, and $\mathrm{SH}$. Dextrans with molecular weights 670,150 , and $50 \mathrm{kDa}$ were utilized as the standards.

\subsection{Antioxidant Activities for SH1, SH2, and SH3}

Previous studies suggested that neuronal damage may be caused by an increase of free radical damage due to oxidative stress [2]. Thus, the antioxidant activities for SH1-SH3 warranted investigation. Three methodologies termed 2,2-diphenyl-1-picrylhydrazyl (DPPH), 2,2'-azino-bis(3-ethylbenzothiazoline-6-sulphonic acid) diammonium salt (ABTS), and ferric reducing antioxidant power (FRAP) analyses were applied in the present study to evaluate the antioxidant activities of SH1-SH3. Table 3 shows the $\mathrm{IC}_{50}$ of DPPH radical scavenging activity for SH1-SH3 ranged from $1.72 \pm 0.07$ to $2.58 \pm 0.03(\mathrm{mg} / \mathrm{mL})$; the $\mathrm{IC}_{50}$ of $\mathrm{ABTS}^{\bullet+}$ scavenging activity for $\mathrm{SH} 1-\mathrm{SH} 3$ ranged from $0.17 \pm 0.01$ to $0.34 \pm 0.00(\mathrm{mg} / \mathrm{mL})$; and the FRAP values ranged from $13.10 \pm 0.06$ to 
$18.36 \pm 0.11$ ( $\mu \mathrm{mol}$ vitamin $\mathrm{C} / \mathrm{g}$ extract, dry basis). Since all fucoidan extracts SH1-SH3 exhibited antioxidant activities, further studies are needed to fully elucidate their neuroprotective functions.

Table 3. Antioxidant activities for SH1, SH2, and SH3.

\begin{tabular}{|c|c|c|c|}
\hline Antioxidant Activity & $\mathrm{SH}^{2}{ }^{2}$ & $\mathrm{SH}^{2}{ }^{2}$ & $\mathrm{SH}^{2}{ }^{2}$ \\
\hline $\mathrm{DPPH} / \mathrm{IC}_{50}(\mathrm{mg} / \mathrm{mL})^{1}$ & $1.72 \pm 0.07^{\mathrm{a}}$ & $2.42 \pm 0.15^{b}$ & $2.58 \pm 0.03^{b}$ \\
\hline $\mathrm{ABTS} / \mathrm{IC}_{50}(\mathrm{mg} / \mathrm{mL})^{1}$ & $0.17 \pm 0.01^{a}$ & $0.26 \pm 0.00^{b}$ & $0.34 \pm 0.00^{c}$ \\
\hline $\begin{array}{l}\text { FRAP/vitamin C equivalent ( } \mu \text { mol } \\
\text { vitamin } C / \text { g extract, dry basis) }\end{array}$ & $18.36 \pm 0.11^{\mathrm{c}}$ & $15.81 \pm 0.24^{b}$ & $13.10 \pm 0.06^{\mathrm{a}}$ \\
\hline
\end{tabular}

${ }^{1} \mathrm{IC}_{50}$ value: concentration of fucoidan capable of scavenging $50 \%$ of DPPH or ABTS free radicals; ${ }^{2}$ values are mean $\pm \mathrm{SD}(n=3)$; means in the same row followed by the different letters (in ${ }^{\mathrm{a}}, \mathrm{b}$, and ${ }^{\mathrm{c}}$ ) are significantly different $(p<0.05)$.

\subsection{Effects of SH1, SH2, and SH3 on 6-OHDA-Induced Apoptosis in SH-SY5Y Cells}

A variety of studies have provided evidence showing that neuronal apoptosis leads to the pathogenesis of acute and chronic neurodegenerative diseases in the adult brain following metabolic or neurotoxic insults [26,27]. PD is a well-known neurodegenerative disorder and is characterized by various symptoms including postural instability, gait abnormality, rest tremors, bradykinesia, and rigidity [28]. The potential mechanisms of PD-associated neurodegeneration can be explored by using an animal PD model. One of the neurotoxins which can induce PD in an animal model is 6-OHDA. 6-OHDA, an oxidative metabolite of dopamine, can either undergo extracellular autooxidation or intracellular enzymatic oxidation through the monoamine oxidase type B, yielding ROS and quinolinic products [29]. Thus, 6-OHDA has been broadly used to generate experimental models of PD [30]. An in vitro model widely used in PD research is the neuroblastoma SH-SY5Y cell line [31]. Both undifferentiated and differentiated SH-SY5Y cells have been utilized for in vitro experiments requiring neuronal-like cells. In general, the most common method employed for the differentiation of SH-SY5Y cells is the addition of retinoic acid (RA) in concentrations ranging from $5 \mu \mathrm{M}$ to $100 \mu \mathrm{M}$, and for a period of time from 1 day up to 21 days [31]; generally, the process is complicated. Sometimes, the RA treatment may also influence the expression of neuronal and dopaminergic markers and affect the susceptibility to dopaminergic neurotoxins in SH-SY5Y cells [32,33]. In addition, it was reported that 784 out of the 962 papers used no differentiation protocols in SH-SY5Y experiments [31]. Moreover, Cheung et al. reported that RA-differentiation conferred higher tolerance in SH-SY5Y cells, potentially by up-regulating survival signaling, including the Akt pathway, and thus the actual toxicity induced by 6-OHDA cannot be revealed in RA-differentiated cells. They therefore suggested that undifferentiated SH-SY5Y is more appropriate for studying neurotoxicity or neuroprotection in experimental Parkinson's disease research [33]. As such, undifferentiated SH-SY5Y cells were adopted in the present study. Here, we examined the protective effects of SH1-SH3 on 6-OHDA-induced dopaminergic neuronal cell death in SH-SY5Y cells. When SH-SY5Y cells were treated with various concentrations of 6-OHDA, the cell viability was decreased in response to the incremental increases in 6-OHDA concentration (Figure 2A). The treatment of SH-SY5Y cells with $75 \mu \mathrm{M} 6-\mathrm{OHDA}$ for $24 \mathrm{~h}$ decreased the cell viability and the value was $44.01 \% \pm 0.83 \%$ of the control group (Figure $2 \mathrm{~A}$ ). Thus, the concentration of $75 \mu \mathrm{M}$ 6-OHDA was utilized for further cellular experiments. To evaluate the cytotoxic effects of SH1-SH3 on SH-SY5Y cells, the cells were treated with different concentrations of SH1-SH3 for $24 \mathrm{~h}$, and then the cell viability of SH-SY5Y cells was evaluated. None of the fucoidan extracts SH1-SH3 exhibited cytotoxicity to SH-SY5Y cells at concentrations from 0 to $500 \mu \mathrm{g} / \mathrm{mL}$ (Figure 2B). In addition, the treatment of SH-SY5Y cells with $75 \mu \mathrm{M}$ 6-OHDA for 24 h decreased the cell viability, and pretreatment of SH-SY5Y cells with SH1-SH3 at concentrations of $125-500 \mu \mathrm{g} / \mathrm{mL}$ for $6 \mathrm{~h}$ dose-dependently attenuated 6-OHDA-induced cellular cytotoxicity (Figure 2C). In general, $\mathrm{SH} 3$ had a greater effect on reversion of 6-OHDA-induced cytotoxicity as compared to SH1 and SH2. 
6-OHDA is known as an apoptosis inducer in various cell types [34]. In order to further examine the protective effects of SH1-SH3 on 6-OHDA-induced apoptosis in SH-SY5Y cells, the cell cycle distribution, cytochrome $c$ release, activation of caspase- $8,-9$, and -3 , and DNA fragmentation were performed by flow cytometry. The flow cytometry is capable of detecting apoptotic dead cells and cells with fragmented nuclei (also called $s u b-G_{1}$ cells) when stained with propidium iodide (PI) [35]. The results in Figure 3A,B show that, in the cell populations of the $s u b-G_{1}, G_{0} / G_{1}, S$, and $G_{2} / M$ phases, the fucoidan extracts SH1-SH3 had a similar cell cycle distribution profile to that of SH-SY5Y cells as compared to the control. When SH-SY5Y cells were treated with $75 \mu \mathrm{M}$ 6-OHDA, a significant increase $(36.45 \% \pm 0.88 \%, p<0.05)$ in the proportion of cells with sub- $G_{1}$ DNA content as compared to control cells $(0.49 \% \pm 0.07 \%)$. Additionally, decreased cell populations of $G_{0} / G_{1}, S$, and $G_{2} / M$ phases in the 6-OHDA-treated cells were also observed as compared to control cells (Figure 3A,B). These results suggest that 6-OHDA caused SH-SY5Y cell cycle arrest at the sub- $G_{1}$ phase. Moreover, treatment of SH-SY5Y cells with $75 \mu \mathrm{M}$ 6-OHDA in the presence of $500 \mu \mathrm{g} / \mathrm{mL}$ SH1, SH2, or SH3 significantly attenuated the $s u b-G_{1}$ populations to $5.25 \% \pm 0.05 \%, 3.57 \% \pm 0.10 \%$, and $2.07 \% \pm 0.07 \%$, respectively $(p<0.05)$. These findings suggest that 6-OHDA could obviously increase the percentage of cells with $s u b-G_{1}$ DNA content, an indicator of greater DNA fragmentation as well as apoptosis or cell cycle arrest at the sub- $G_{1}$ phase. In addition, treatment of cells with SH1, SH2, or SH3 significantly attenuated the sub-G $G_{1}$ populations of 6-OHDA-induced apoptotic cells, indicating that $\mathrm{SH} 1, \mathrm{SH} 2$, and $\mathrm{SH} 3$ could protect $\mathrm{SH}-\mathrm{SY} 5 \mathrm{Y}$ cells against neurotoxicity. We also found that $\mathrm{SH} 3$ was the most effective at reducing the sub-G 1 population in 6-OHDA-treated SH-SY5Y cells, followed by SH2, and then SH1. Cytochrome c release from mitochondria to cytosol is a hallmark of apoptosis and is often utilized to characterize the mitochondria-dependent apoptotic pathway [36]. Here, an immunodetection of cytochrome c by flow cytometry was applied to quantify release of cytochrome $\mathrm{c}$ in cells. As shown in Figure $4 \mathrm{~A}, \mathrm{~B}$, the fucoidan extracts $\mathrm{SH} 1-\mathrm{SH} 3$ possessed a similar cytometric profile to that of SH-SY5Y cells as compared to the control. When cells were treated with $75 \mu \mathrm{M}$ 6-OHDA, the population of high fluorescent cells decreased from $96.80 \% \pm 0.22 \%$ (control) to $43.47 \% \pm 0.53 \%$, indicating cytochrome c underwent release from mitochondria. In contrast, when cells were treated with $75 \mu \mathrm{M}$ 6-OHDA in the presence of $500 \mu \mathrm{g} / \mathrm{mL} \mathrm{SH} 1, \mathrm{SH} 2$, or SH3, the populations of high fluorescent cells were significantly increased to $56.90 \% \pm 0.33 \%, 55.43 \% \pm 0.77 \%$, and $64.27 \% \pm 2.46 \%$, respectively. These results clearly indicate that SH1-SH3 may protect SH-SY5Y cells from the 6-OHDA-induced mitochondria-dependent apoptotic effect. In addition, SH3 was more effective at preventing 6-OHDA-induced cytochrome c release in cells than SH1 and SH2. There are two basic mechanisms involved in the induction of apoptosis, the extrinsic pathway (death receptor-mediated) and the intrinsic pathway (regulated at the level of the mitochondria). The extrinsic pathway of apoptosis signals through cell surface molecules like Fas/FasL resulting in the recruitment of the Fas-associated death domain (FADD). The FADD associates with Fas and recruits pro-caspase- 8 . This active complex is referred to as the death-inducing signaling complex (DISC). The DISC activates caspase-3, and then apoptosis occurs. The intrinsic pathway occurs following loss of mitochondrial transmembrane potential (MTP), resulting in the release of cytochrome $\mathrm{c}$ into the cytoplasm. Cytochrome $\mathrm{c}$ forms a complex with the cytoplasmic protein Apaf- 1 and pro-caspase- 9 that is termed the "apoptosome" that results in activation of caspase- 3 , leading to systematic disassembly of the cell [37]. Thus, the activation of caspases such as caspase-8, -9 , and -3 is the typical hallmark of apoptosis. Here, we measured active caspase- $8,-9$, and -3 in cells using a flow cytometric-based analysis. As shown in Figure 5A,B, when cells were treated with $75 \mu \mathrm{M}$ 6-OHDA, the population of high fluorescent cells for the caspase- 8 group increased from $0.87 \% \pm 0.09 \%$ (control) to $60.47 \% \pm 0.78 \%$, indicating the augmentation of active caspase- 8 . Conversely, when cells were treated with $75 \mu \mathrm{M}$ 6-OHDA in the presence of $500 \mu \mathrm{g} / \mathrm{mL} \mathrm{SH1}$, SH2, or $\mathrm{SH} 3$, the population of high fluorescent cells was significantly decreased to $20.50 \% \pm 0.22 \%, 20.17 \%$ $\pm 0.33 \%$, and $16.40 \% \pm 0.37 \%$, respectively. A similar tendency was also observed in the caspase- 9 and caspase- 3 groups. These results clearly indicate that SH1-SH3 may protect SH-SY5Y cells from 6-OHDA-induced activation of caspase- $8,-9$, and -3 . In addition, SH3 was more effective at preventing 
6-OHDA-induced activation of caspase- $8,-9$, and -3 in cells than $\mathrm{SH} 1$ and $\mathrm{SH} 2$. In the event of apoptosis, both the extrinsic pathway and the intrinsic pathway result in the activation of caspase- 3 . Caspase- 3 seems to play a central role in apoptotic events and is specifically required for DNA fragmentation leading to the typical apoptotic pattern of DNA laddering [38,39]. Therefore, the detection of DNA fragmentation (a hallmark of late-stage apoptosis) in cells was performed by flow cytometric-based terminal deoxynucleotidyl transferase-mediated dUTP nick end-labeling (TUNEL) assay. As shown in Figure 6A,B, the fucoidan extracts $\mathrm{SH} 1-\mathrm{SH} 3$ possessed a similar cytometric profile to that of SH-SY5Y cells as compared to the control. When cells were treated with $75 \mu \mathrm{M} 6-\mathrm{OHDA}$, the population of high fluorescent cells significantly increased from $1.57 \% \pm 0.12 \%$ (control) to $14.73 \% \pm 0.85 \%$, indicating the occurrence of DNA fragmentation. In contrast, when cells were treated with $75 \mu \mathrm{M}$ 6-OHDA in the presence of $500 \mu \mathrm{g} / \mathrm{mL} \mathrm{SH1}, \mathrm{SH} 2$, or SH3, the population of high fluorescent cells was significantly decreased to $4.43 \% \pm 0.54 \%, 3.23 \% \pm 0.66 \%$, and $4.03 \% \pm 0.65 \%$, respectively. These results clearly show that SH1-SH3 may protect SH-SY5Y cells from 6-OHDA-induced DNA fragmentation of cells. In summary, all of the treated fucoidan extracts $\mathrm{SH} 1-\mathrm{SH} 3$ protected SH-SY5Y cells from 6-OHDA-induced apoptosis as illustrated by the cell cycle distribution, cytochrome c release, activation of caspase-8, -9 , and -3 , and DNA fragmentation analyses. Among SH1-SH3, SH3 generally exhibited the greatest neuroprotective effects. The neuroprotective effects of SH3 may be positively correlated to the high total sugar content, high molar ratio of sulfate/fucose, and low molecular weight in SH3. Further experimental studies using differentiated SH-SY5Y cells or in vivo models are needed to elucidate the precise mechanisms involved. Since SH3 had a relatively high extraction yield, a relatively low level of impurities, and the greatest neuroprotective effects, we thus suggest that SH3 could be a good candidate for application in the preventive therapy of neurodegenerative diseases, especially PD.
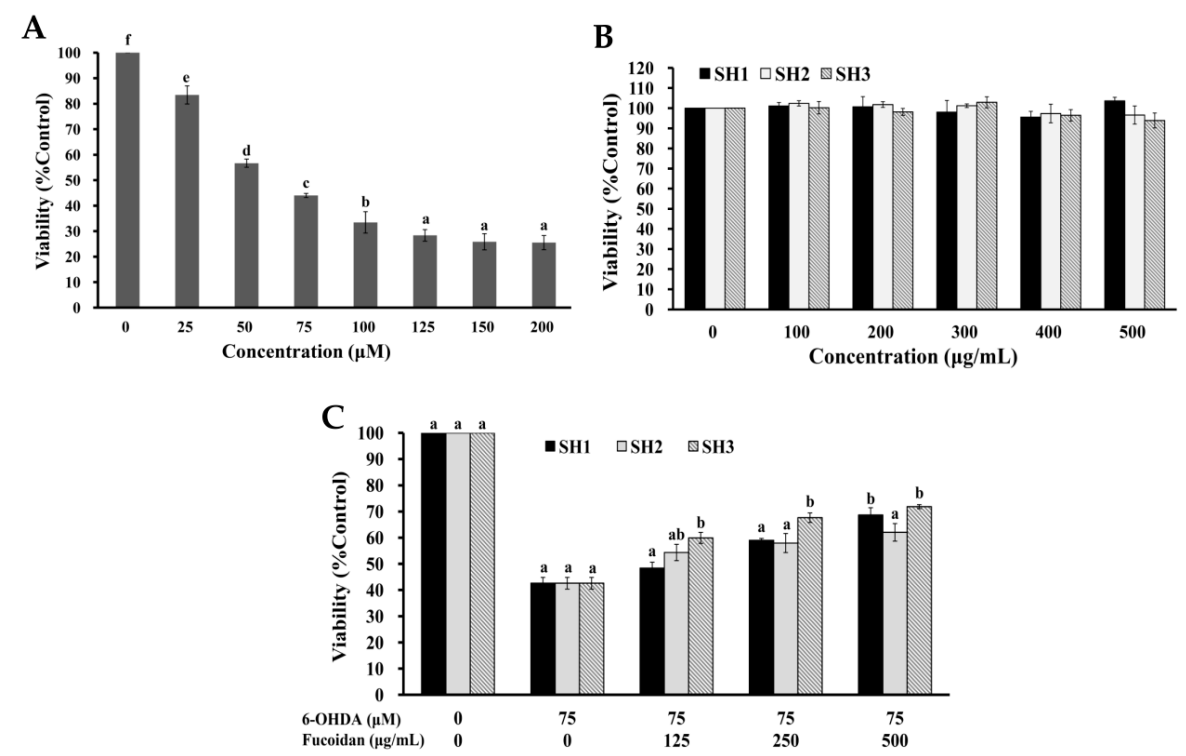

Figure 2. Effects of crude extracts of fucoidans (SH1, SH2, and SH3) and 6-OHDA treatment with or without SH1-SH3 pretreatment on cell viability of SH-SY5Y cells: (A) SH-SY5Y cells were treated with 6-OHDA (0-200 $\mu \mathrm{M})$ for $24 \mathrm{~h}$, and cell viability was assessed. Values are expressed as the mean $\pm \mathrm{SD}$ $(n=3)$; (B) SH-SY5Y cells were treated with SH1, SH2, or SH3 $(0-500 \mu \mathrm{g} / \mathrm{mL})$ for $24 \mathrm{~h}$, and cell viability was assessed. Values are expressed as the mean $\pm \mathrm{SD}(n=3)$; (C) SH-SY5Y cells were pretreated with SH1, $\mathrm{SH} 2$, or SH3 $(0-500 \mu \mathrm{g} / \mathrm{mL})$ for $6 \mathrm{~h}$, followed by treatment with $75 \mu \mathrm{M}$ 6-OHDA for $24 \mathrm{~h}$, and cell viability was assessed. Values are expressed as the mean $\pm \mathrm{SD}(n=3)$. Different letters (in $\mathrm{a}, \mathrm{b}, \mathrm{c}, \mathrm{d}, \mathrm{e}$, and $\mathrm{f}$ ) mean statistically significant differences at $p<0.05$. In each group of columns related to each concentration of fucoidan, the means that have at least one common letter do not differ significantly $(p>0.05)$. 
A
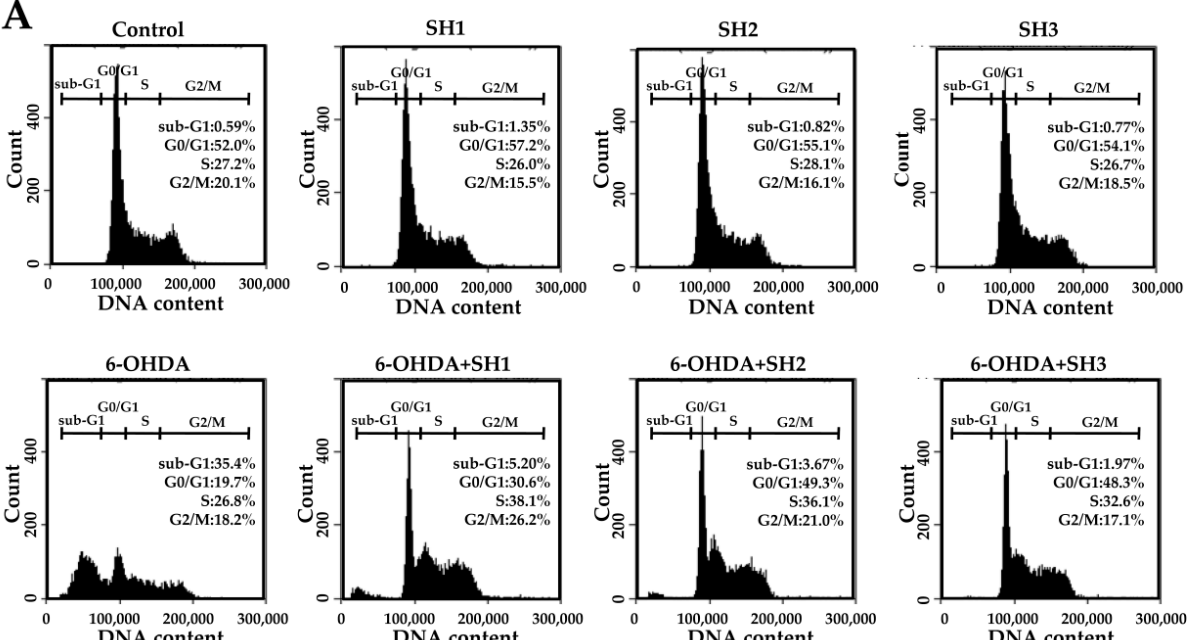

B

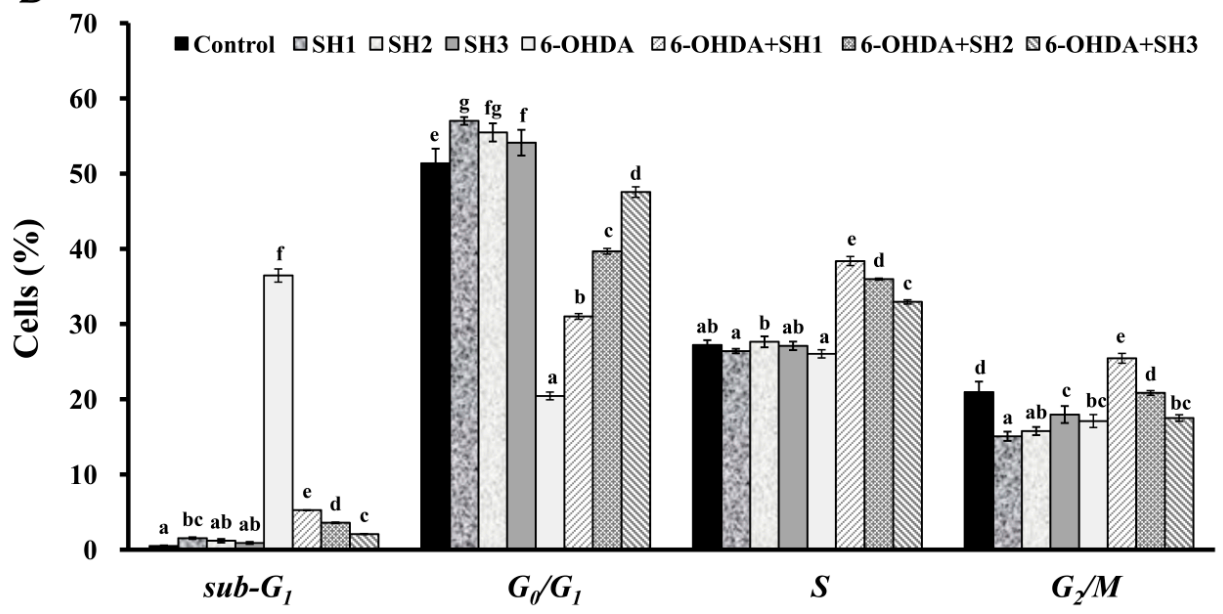

Figure 3. Effects of 6-OHDA treatment with or without $\mathrm{SH} 1-\mathrm{SH} 3$ pretreatment on cell cycle profiles of SH-SY5Y cells: (A) SH-SY5Y cells were pretreated with $\mathrm{SH} 1, \mathrm{SH} 2$, or $\mathrm{SH} 3$ at a concentration of $500 \mu \mathrm{g} / \mathrm{mL}$ for $6 \mathrm{~h}$, followed by treatment with or without $75 \mu \mathrm{M}$ 6-OHDA for $24 \mathrm{~h}$, and cell cycle profiles were assessed; (B) summarizing bar graph of three cell cytometric analyses showing the percentages of cells in the $s u b-G_{1}, G_{0} / G_{1}, S$, and $G_{2} / M$ phases of the cell cycle according to treatments after analysis using BD Accuri C6 software. Results are shown as mean \pm SD of three independent experiments. Different letters (in a, b, c, d, e, f, and g) mean statistically significant differences at $p<0.05$. In each group of columns related to each cell cycle phase, differences exist between columns labeled with different letters, $p<0.05$. 
A

Control

SH1
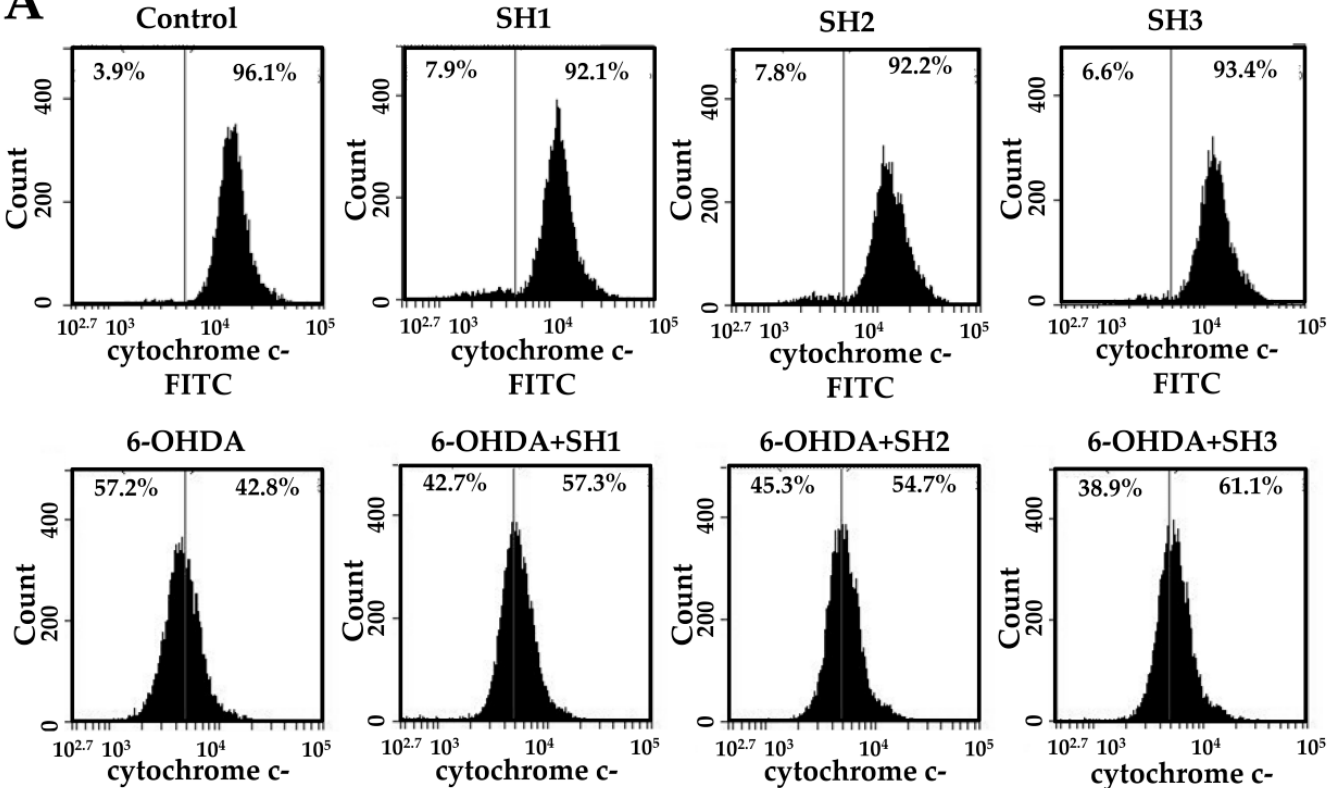

FITC

FITC

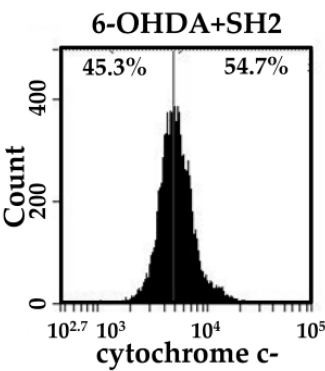

FITC

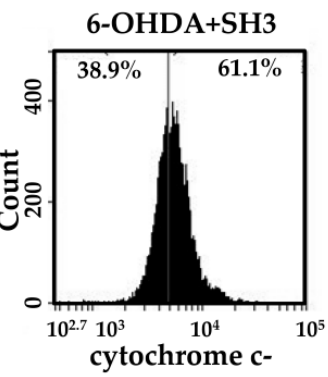

FITC

B

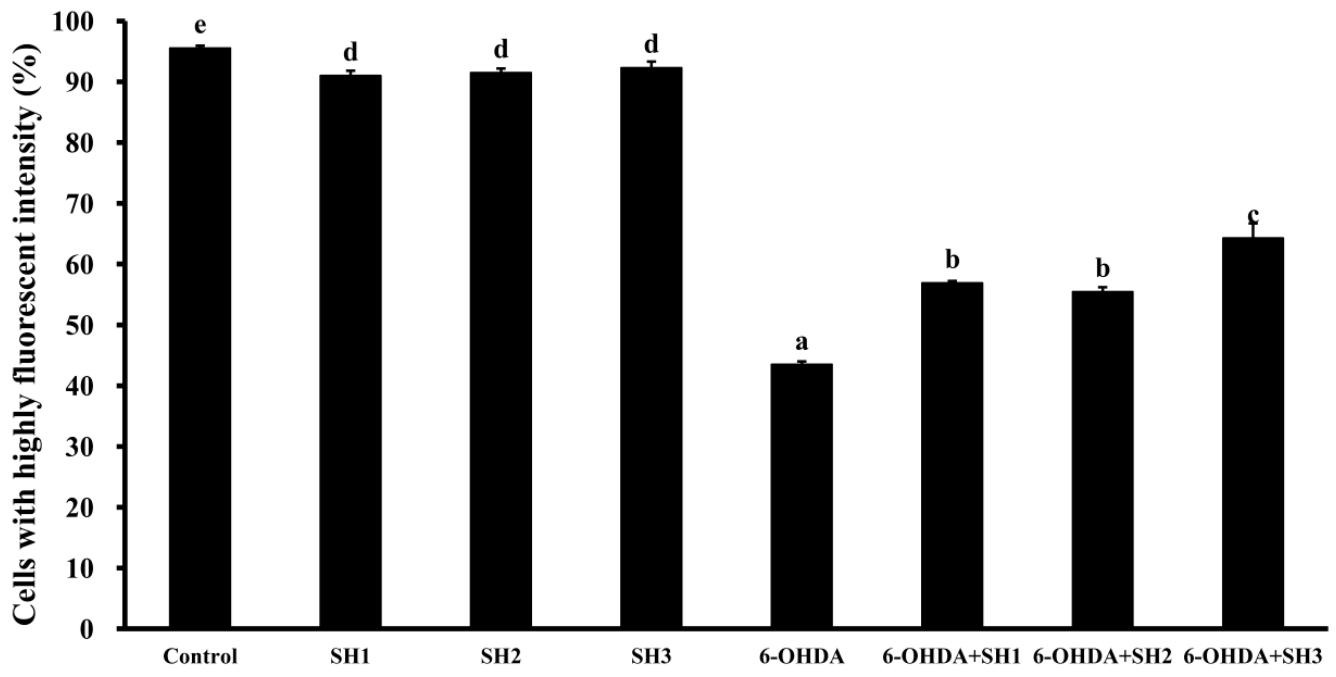

Figure 4. Effects of 6-OHDA treatment with or without $\mathrm{SH} 1-\mathrm{SH} 3$ pretreatment on the extent of cytochrome c release in SH-SY5Y cells: (A) SH-SY5Y cells were pretreated with SH1, SH2, or SH3 at a concentration of $500 \mu \mathrm{g} / \mathrm{mL}$ for $6 \mathrm{~h}$, followed by treatment with or without $75 \mu \mathrm{M}$ 6-OHDA for $24 \mathrm{~h}$, and fluorescence histograms of immunolabeled cytochrome c were assessed; (B) summarizing bar graph of three cell cytometric analyses showing the percentages of cells with highly fluorescent intensity according to treatments after analysis using BD Accuri C6 software. Results are shown as mean \pm SD of three independent experiments. Different letters (in a, b, c, d, and e) mean statistically significant differences at $p<0.05$. Differences exist between columns labeled with different letters, $p<0.05$. 
A
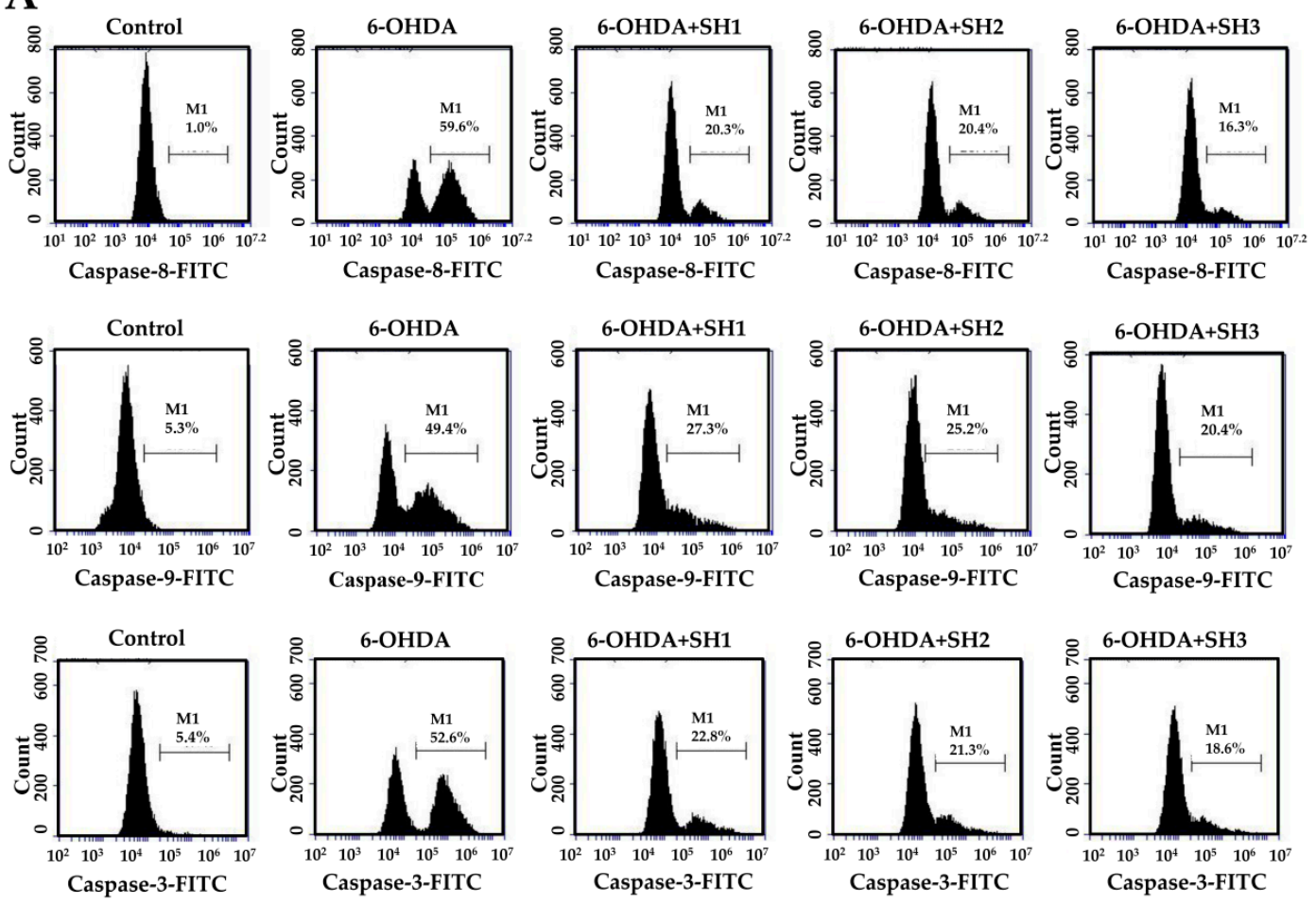

B

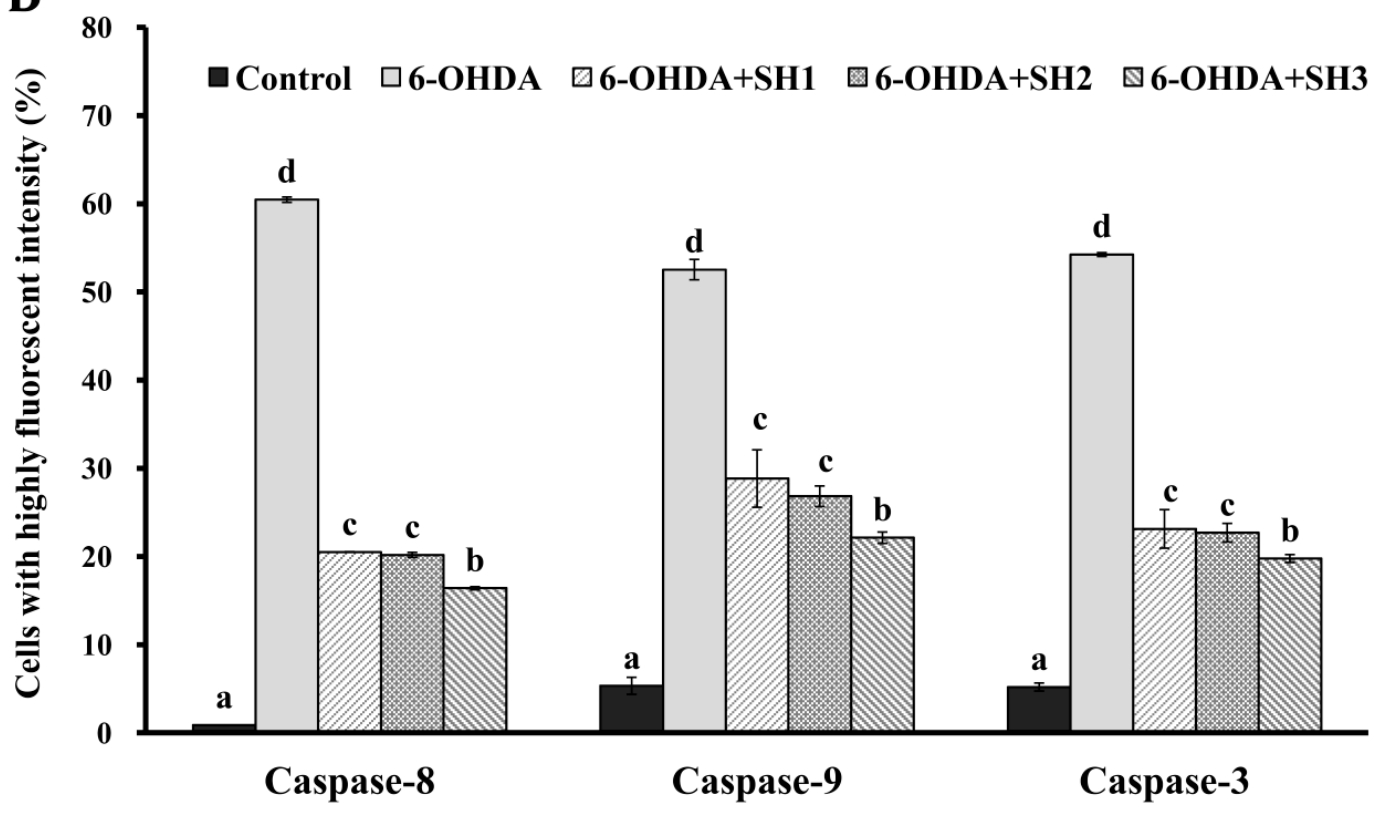

Figure 5. Effects of 6-OHDA treatment with or without $\mathrm{SH} 1-\mathrm{SH} 3$ pretreatment on active caspase-8, -9, and -3 in SH-SY5Y cells: (A) SH-SY5Y cells were pretreated with SH1, SH2, or SH3 at a concentration of $500 \mu \mathrm{g} / \mathrm{mL}$ for $6 \mathrm{~h}$, followed by treatment with $75 \mu \mathrm{M} 6-\mathrm{OHDA}$ for $24 \mathrm{~h}$, and fluorescence histograms of immunolabeled caspase-8, -9 , and -3 were assessed; (B) summarizing bar graph of three cell cytometric analyses and showing the percentages of cells with highly fluorescent intensity according to treatments after analysis using BD Accuri C6 software. Results are shown as mean \pm SD of three independent experiments. Different letters (in a, b, c, and d) mean statistically significant differences at $p<0.05$. In each group of columns related to each type of caspase, differences exist between columns labeled with different letters, $p<0.05$. 
A
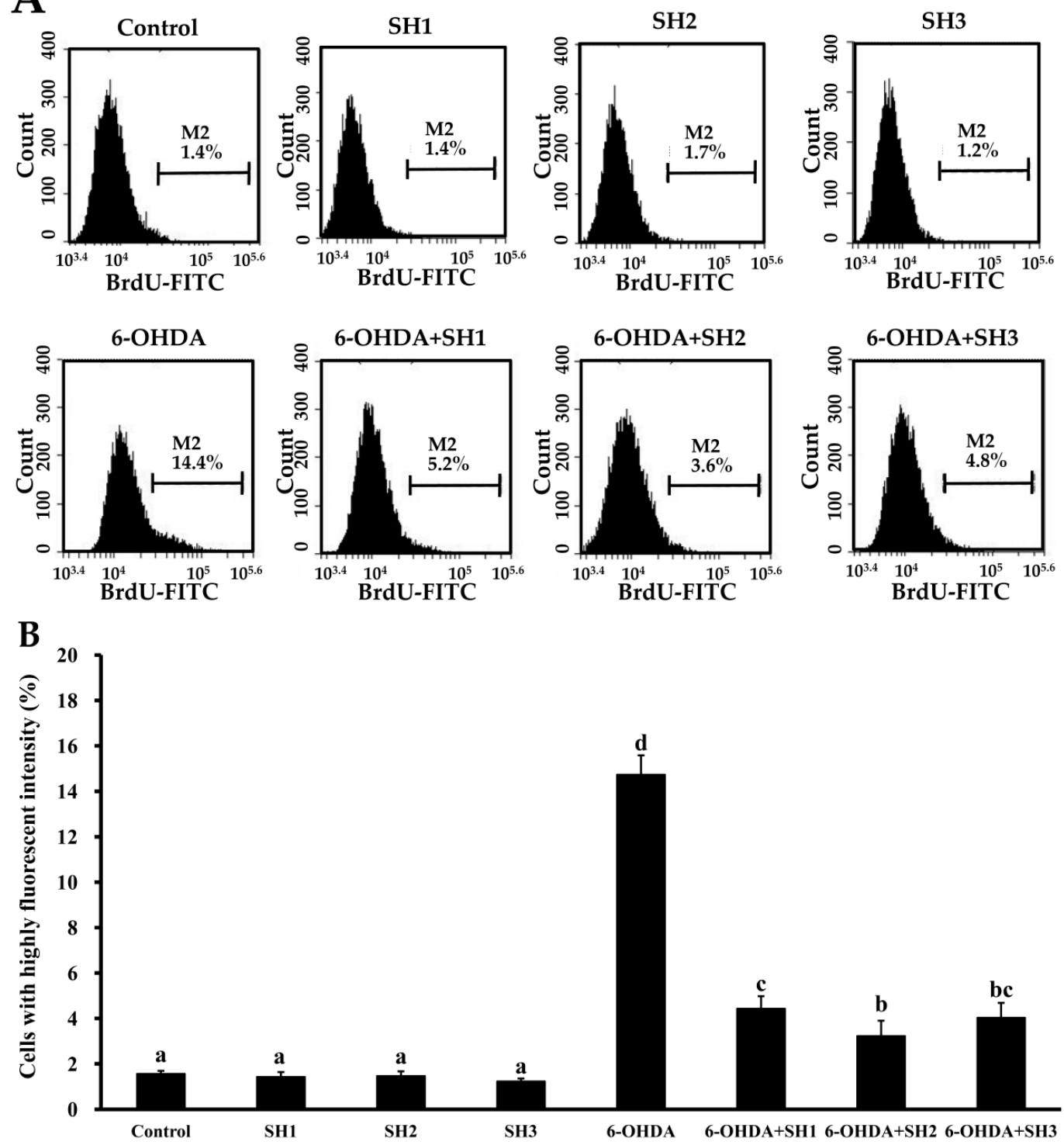

Figure 6. Effects of 6-OHDA treatment with or without $\mathrm{SH} 1-\mathrm{SH} 3$ pretreatment on the extent of DNA fragmentation in SH-SY5Y cells: (A) SH-SY5Y cells were pretreated with SH1, SH2, or SH3 at a concentration of $500 \mu \mathrm{g} / \mathrm{mL}$ for $6 \mathrm{~h}$, followed by treatment with or without $75 \mu \mathrm{M}$ 6-OHDA for $24 \mathrm{~h}$, and fluorescence histograms of immunolabeled BrdU were assessed; (B) summarizing bar graph of three cell cytometric analyses showing the percentages of cells with highly fluorescent intensity according to treatments after analysis using BD Accuri C6 software. Results are shown as mean \pm SD of three independent experiments. Different letters (in a, b, c, and d) mean statistically significant differences at $p<0.05$. Differences exist between columns labeled with different letters, $p<0.05$.

\subsection{Phosphorylation of Akt Is Involved in the Neuroprotective Effects of SH1, SH2, and SH3 on 6-OHDA-Induced Apoptosis in SH-SY5Y Cells}

PI3Ks/protein kinase B (PKB or Akt) pathway has vital roles in the differentiation, survival, cell cycle, metabolism, cytokine production, growth, and activation of B cells [40]. Previous studies suggested that the PI3K/Akt pathway is involved in the prevention of apoptotic cell death in a PD model of SH-SY5Y cells [41]. We thus evaluated the expressions of phosphorylated Akt (p-Akt) and total Akt (Akt1) in cells by flow cytometry. As shown in Figure 7A,B, it was found that fucoidan extracts SH1-SH3 possessed a cytometric profile of p-Akt and Akt1 expressions that was similar to that of SH-SY5Y cells as compared to the control. When cells were treated with $75 \mu \mathrm{M}$ 6-OHDA, 
the population of high fluorescent cells significantly decreased from $94.50 \% \pm 0.14 \%$ (control) to $64.10 \% \pm 0.79 \%$, indicating the occurrence of dephosphorylation of Akt. Conversely, when cells were treated with $75 \mu \mathrm{M}$ 6-OHDA in the presence of $500 \mu \mathrm{g} / \mathrm{mL} \mathrm{SH1}$, SH2, or SH3, the population of high fluorescent cells was significantly increased to $82.43 \% \pm 0.24 \%, 86.27 \% \pm 0.53 \%$, and $82.90 \%$ $\pm 0.85 \%$, respectively. These results clearly indicate that $\mathrm{SH} 1-\mathrm{SH} 3$ may protect $\mathrm{SH}-\mathrm{SY} 5 \mathrm{Y}$ cells from 6-OHDA-induced dephosphorylation of Akt in cells. In addition, when examining the expression of Akt1, it was found the expression level of Akt1 was not changed with respect to different treatments. Our results provide evidence that phosphorylation of Akt is involved in the preventive effects of SH1-SH3 on 6-OHDA-induced neurotoxicity. Further elucidation of the molecular mechanism and signaling cascade underlying the neuroprotective effects of SH1-SH3 (especially SH3) is warranted.
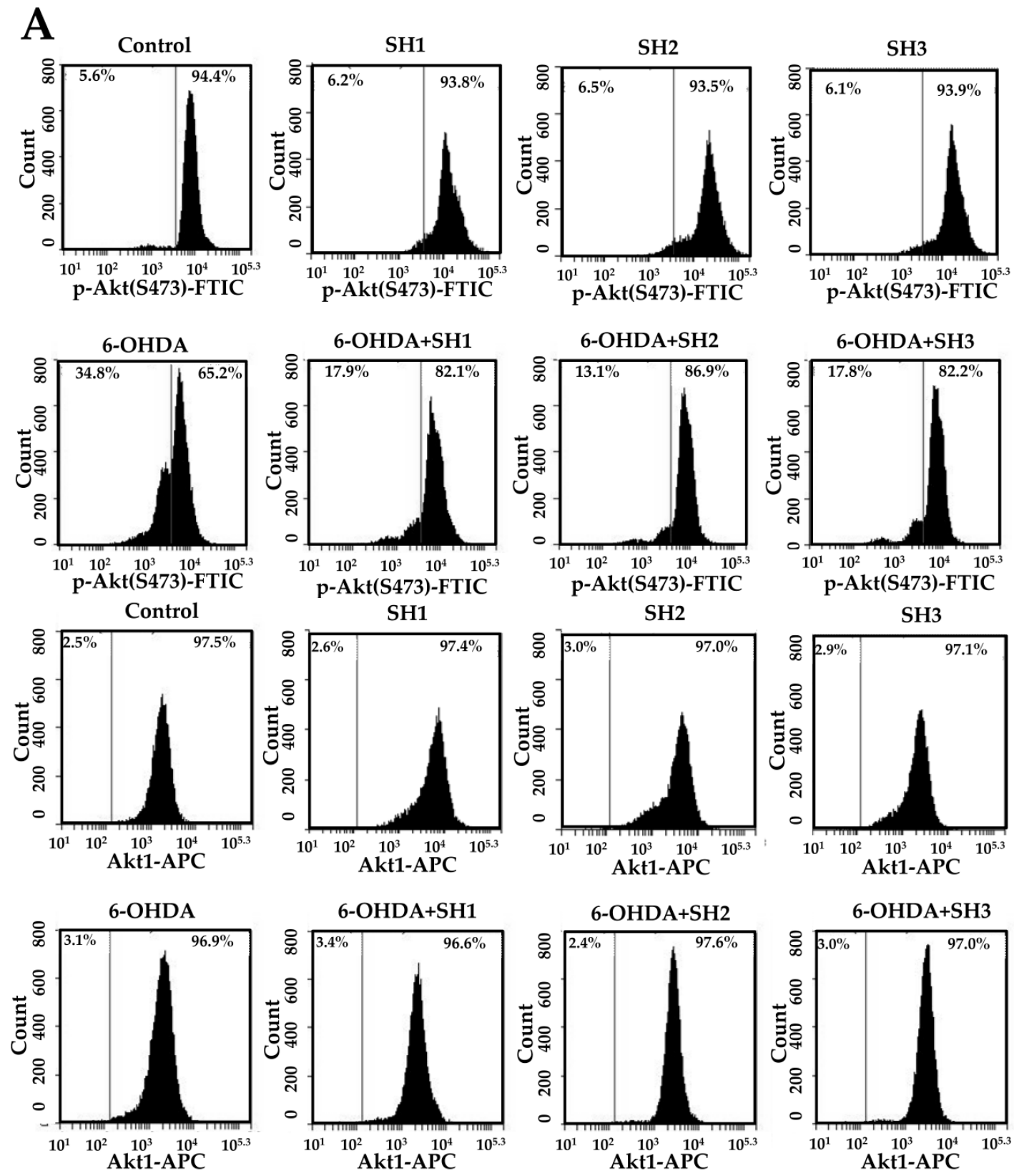

Figure 7. Cont. 


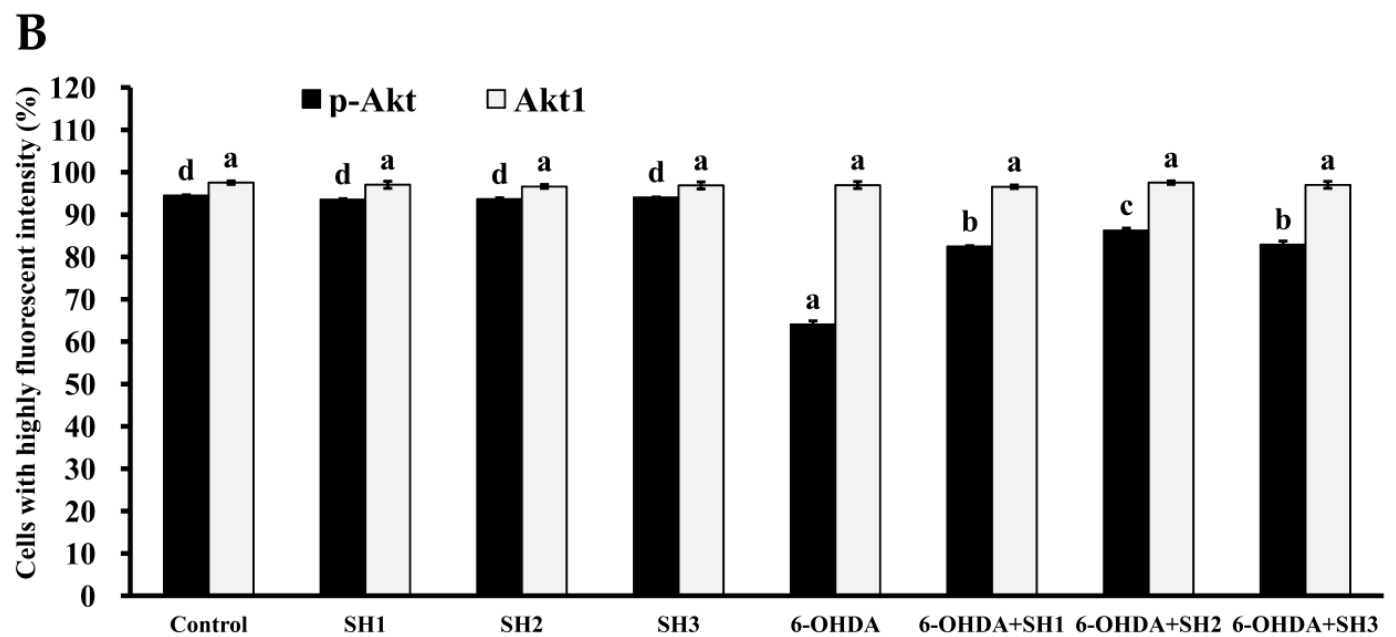

Figure 7. Effects of 6-OHDA treatment with or without $\mathrm{SH} 1-\mathrm{SH} 3$ pretreatment on the expression of p-Akt and Akt1 in SH-SY5Y cells: (A) SH-SY5Y cells were pretreated with SH1, SH2, or SH3 at a concentration of $500 \mu \mathrm{g} / \mathrm{mL}$ for $6 \mathrm{~h}$, followed by treatment with or without $75 \mu \mathrm{M}$ 6-OHDA for $24 \mathrm{~h}$, and fluorescence histograms of immunolabeled p-Akt and Akt1 were assessed; (B) summarizing bar graph of three cell cytometric analyses showing the percentages of cells with highly fluorescent intensity according to treatments after analysis using BD Accuri C6 software. Results are shown as mean \pm SD of three independent experiments. Different letters (in a, b, c, and d) mean statistically significant differences at $p<0.05$. In each group of columns related to $\mathrm{p}$-Akt or Akt1, differences exist between columns labeled with different letters, $p<0.05$.

\section{Materials and Methods}

\subsection{Materials and Chemicals}

A sample of S. hemiphyllum (SH) was collected from Pingtung, Taiwan and then washed with fresh water, oven-dried at $50{ }^{\circ} \mathrm{C}$, and kept in plastic bags at $4{ }^{\circ} \mathrm{C}$ until further experiments. L-fucose, L-rhamnose, D-glucose, D-glucuronic acid, D-galactose, D-mannose, D-xylose, D-galacturonic acid, gallic acid, sodium carbonate, potassium sulfate, DPPH, ABTS, 2,4,6-tris(2-pyridyl)-s-triazine (TPTZ), sodium acetate trihydrate, thioglycolic acid solution, 3-(4,5-dimethylthiazol-2-yl)-2,5-diphenyltetrazolium bromide (MTT), 6-OHDA, bovine serum albumin (BSA), Bradford reagent, and dimethyl sulfoxide (DMSO) were obtained from Sigma-Aldrich (St. Louis, MO, USA). 2,2,2-Trifluoroacetic acid (TFA) was obtained from Panreac (Barcelona, Spain). Potassium persulfate, potassium bromide (KBr), and sodium sulfite were purchased from Merck (Darmstadt, Germany). Fetal bovine serum (FBS), trypsin/EDTA, penicillin, and streptomycin were obtained from Gibco Laboratories (Grand Island, NY, USA). Dulbecco's Modification of Eagle's Medium/Ham's F-12 50/50 Mix medium was obtained from Corning (Corning, NY, USA). All other reagents were of analytical grade or the best grade available.

\subsection{Compressional-Puffing Procedure}

The dried algal sample (weight $=2.7 \mathrm{~g}, \mathrm{H}_{2} \mathrm{O}=12.9 \%$ ) was puffed according to our previously described procedure [6,7]. The detailed operational parameters are described in Table 1.

\subsection{Water Extraction Procedure}

The water extraction procedure for obtaining fucoidan was performed according to our previously described protocol [7] with slight modification. In brief, the compressional-puffed algal sample was mixed with $95 \%$ ethanol $(w / v=1: 10)$, shaken for $4 \mathrm{~h}$ at room temperature to remove pigments, proteins and lipid, and then centrifuged at $970 \times g$ for $10 \mathrm{~min}$. The residue was collected, mixed with 
double-distilled water $(w / v=1: 10)$ and placed in a water bath kept at $85^{\circ} \mathrm{C}$ for $1 \mathrm{~h}$ with shaking $(120 \mathrm{rpm})$ to extract the polysaccharides. The mixture was centrifuged at $3870 \times \mathrm{g}$ for $10 \mathrm{~min}$ and the supernatant was collected. $2 \%(w / v) \mathrm{CaCl}_{2}$ solution was added to the supernatant for $1 \mathrm{~h}$ with shaking $(120 \mathrm{rpm})$ to precipitate alginate. The mixture was centrifuged at $3870 \times g$ for $10 \mathrm{~min}$, and the supernatant was ultrafiltrated $(300 \times g$ for $10 \mathrm{~min}$ ) using $100 \mathrm{kDa}$ membrane for protein and calcium removal. The retentate was collected and ethanol $(95 \%)$ was added into the supernatant to give a final ethanol concentration of $20 \%$ in order to further precipitate alginic acid. The mixture was centrifugated at $9170 \times g$ for $30 \mathrm{~min}$, the supernatant was collected, and $95 \%$ ethanol was added until a final ethanol concentration of $50 \%$ was reached in order to obtain fucoidan precipitate. The ethanol-precipitated fucoidan was then recovered by centrifugation at $9170 \times g$ for $30 \mathrm{~min}$ and lyophilized. Extraction yield was calculated using the following equation:

$$
\text { Extraction yield }(\%)=\left(g_{\mathrm{A}} / g_{\mathrm{B}}\right) \times 100
$$

where $g_{\mathrm{A}}$ represents the weight of the extracted solid on a dry basis, and $g_{\mathrm{B}}$ is the weight of the sample on a dry basis.

\subsection{Chemical Methods}

The determinations of crude protein, fat, moisture, and ash were carried out using the following AOAC procedures. Carbohydrate was calculated as weight differences between the total weight and the sum of the amounts of moisture, protein, lipid, and ash. The phenol-sulfuric acid colorimetric method was used to determine the total sugar content, and using L-fucose as the standard. The fucose content was determined by the method of Gibbons [42], and L-fucose was used as the standard. Protein in the extract was quantified by the Bradford method using BSA as the standard. Uronic acids were estimated by the colorimetric method using D-galacturonic acid as the standard [43]. Alginate content was measured according to the method of Honya [44]. Polyphenols were analyzed by the Folin-Ciocalteu method and gallic acid was used as the standard. Sulfate content of polysaccharide was determined by first hydrolyzing the polysaccharide with $1 \mathrm{~N} \mathrm{HCl}$ solution for $5 \mathrm{~h}$ at $105^{\circ} \mathrm{C}$. The hydrolysate was then quantified based on the percentage of sulfate composition using Dionex ICS-1500 Ion Chromatography (Sunnyvale, CA, USA) with an IonPac AS9-HC column $(4 \times 250 \mathrm{~mm})$ at a flow rate of $1 \mathrm{~mL} / \mathrm{min}$ at $30{ }^{\circ} \mathrm{C}$ with conductometric detection. The eluent was $9 \mathrm{mM} \mathrm{Na}{ }_{2} \mathrm{CO}_{3}$, and $\mathrm{K}_{2} \mathrm{SO}_{4}$ was utilized as the standard.

\subsection{Analysis of Monosaccharide Composition}

The monosaccharide composition of polysaccharide was analyzed according to our previously described method [7], using L-fucose, D-xylose, D-galactose, D-glucose, D-glucuronic acid, L-rhamnose, and D-mannose as the standards.

\subsection{NMR Spectroscopy}

A $20 \mathrm{mg}$ polysaccharide sample was dissolved in $550 \mu \mathrm{L}$ of $99.9 \%$ deuterium oxide $\left(\mathrm{D}_{2} \mathrm{O}\right)$ in a NMR tube and ${ }^{1} \mathrm{H}$ NMR spectrum was recorded at $60^{\circ} \mathrm{C}$ on a Varian $400-\mathrm{MR}(400 \mathrm{MHz})$ spectrometer (Agilent Technologies, Santa Clara, CA, USA) for proton detection. The proton chemical shift was expressed in parts per million (ppm).

\subsection{Molecular Weight Analysis}

The molecular weight analysis of the polysaccharides was conducted according to the method of Yang [7]. The standards used to calibrate the column were various dextrans with different molecular weights (50, 150, and $670 \mathrm{kDa}$ ), which were obtained from Sigma-Aldrich (Sigma-Aldrich, St. Louis, MO, USA). 


\subsection{FTIR Spectroscopy}

The FTIR analysis was performed according to the method of Huang [45]. In brief, polysaccharide and $\operatorname{KBr}(w / w, 1: 50)$ were mixed and ground evenly until particles measured less than $2.5 \mu \mathrm{m}$ in size. The transparent $\mathrm{KBr}$ pellets were made at $500 \mathrm{~kg} / \mathrm{cm}^{2}$ under vacuum. The FTIR spectra were obtained using a FT-730 spectrometer (Horiba, Kyoto, Japan), and the absorbance was read between 400 and $4000 \mathrm{~cm}^{-1}$. Pellet of $\mathrm{KBr}$ alone was used as a background.

\subsection{DPPH Radical Scavenging Activity}

The DPPH radical scavenging activity was determined according to a method described elsewhere [35]. Briefly, $50 \mu \mathrm{L}$ of sample was added to $150 \mu \mathrm{L} 0.1 \mathrm{mM}$ freshly prepared DPPH solution (in methanol). The mixture was shaken vigorously for $1 \mathrm{~min}$, left to stand for $30 \mathrm{~min}$ in the dark at room temperature, and the absorbance of all sample solutions was measured at $517 \mathrm{~nm}$ using an ELISA reader (PowerWave 340, Bio-Tek Instruments, Winooski, VT, USA). The radical-scavenging activity was calculated using the following Equation:

$$
\text { DPPHradical - scavenging }(\%)=\left[1-\frac{\mathrm{A}_{\text {sample }}}{\mathrm{A}_{\text {control }}}\right] \times 100
$$

where $\mathrm{A}_{\text {sample }}$ is the absorbance of the methanol solution of DPPH with tested samples, and $\mathrm{A}_{\text {control }}$ represents the absorbance of the methanol solution of DPPH without the sample.

\subsection{ABTS Radical Cation Scavenging Activity}

The scavenging activity of the samples against ABTS radical cation was measured according to a method described elsewhere [35]. In brief, the ABTS ${ }^{\bullet+}$ solution was prepared by reacting $5 \mathrm{~mL}$ of ABTS solution $(7 \mathrm{mM})$ with of $88 \mu \mathrm{L}$ of potassium persulfate $(140 \mathrm{mM})$, and the mixture was kept in the dark at room temperature for $16 \mathrm{~h}$. The solution was diluted with $95 \%$ ethanol to obtain an absorbance of $0.70 \pm 0.05$ at $734 \mathrm{~nm}$. To start the assay, $100 \mu \mathrm{L}$ diluted $\mathrm{ABTS}^{\bullet+}$ solution was mixed with $100 \mu \mathrm{L}$ of various sample solutions. The mixture was allowed to react at room temperature for $6 \mathrm{~min}$, and the absorbance of all sample solutions at $734 \mathrm{~nm}$ was measured using an ELISA reader (PowerWave 340, Bio-Tek Instruments, Winooski, VT, USA). The blank was prepared in the same manner, except that distilled water was used instead of the sample. The activity of scavenging ABTS ${ }^{\bullet+}$ was calculated according to the following Equation:

$$
\text { ABTScation radical - scavenging }(\%)=\left[1-\frac{\mathrm{A}_{\text {sample }}}{\mathrm{A}_{\text {control }}}\right] \times 100
$$

where $\mathrm{A}_{\text {sample }}$ is the absorbance of ABTS with tested samples, and $\mathrm{A}_{\text {control }}$ represents the absorbance of ABTS without the sample.

\subsection{FRAP Assay}

The FRAP assay was performed according to the protocol proposed by Benzie and Strain [46]. Briefly, the FRAP solution was prepared by adjusting $10 \mathrm{~mL}$ of acetate buffer $(300 \mathrm{mM})$ to $\mathrm{pH} 3.6$ via the addition of acetic acid. It was then mixed with $1 \mathrm{~mL}$ of ferric chloride hexahydrate $(20 \mathrm{mM})$ dissolved in distilled water and $1 \mathrm{~mL}$ of TPTZ $(10 \mathrm{mM})$ dissolved in $\mathrm{HCl}(40 \mathrm{mM})$. A volume measuring $25 \mu \mathrm{L}$ of the test sample dissolved at different concentrations was prepared. Freshly prepared FRAP solution $(175 \mu \mathrm{L})$ warmed at $37^{\circ} \mathrm{C}$ was added to the sample, while the same volume of acetate buffer was utilized as the blank. The absorbance at $593 \mathrm{~nm}$ was monitored by an ELISA reader (PowerWave 340, Bio-Tek Instruments, Winooski, VT, USA). Vitamin C was used as a standard and FRAP values were expressed as micromole vitamin $\mathrm{C}$ equivalents per gram of sample on a dry basis ( $\mu \mathrm{mol}$ vitamin $\mathrm{C} / \mathrm{g}$ sample, dry basis). 


\subsection{Cell Culture}

A SH-SY5Y cell line (human dopaminergic, neuroblastoma, ATCC ${ }^{\circledR}$ CRL-2266 ${ }^{\mathrm{TM}}$ ) was obtained from the Food Industry Research and Development Institute, Hsinchu, Taiwan. SH-SY5Y cells were cultured in Dulbecco's Modification of Eagle's Medium/Ham's F-12 50/50 Mix medium supplemented with $10 \%$ FBS, plus streptomycin $(100 \mu \mathrm{g} / \mathrm{mL})$, and penicillin $(100 \mathrm{units} / \mathrm{mL})$ at $37^{\circ} \mathrm{C}$ in the presence of $95 \%$ air, and $5 \% \mathrm{CO}_{2}$. The culture medium was changed every $48-72 \mathrm{~h}$.

\subsection{Cell Viability Test}

Cell viability was measured by quantitative colorimetric MTT assay [35]. Briefly, SH-SY5Y cells $\left(1 \times 10^{5} / \mathrm{mL}\right.$ in a 96-well plate) were plated with culture medium and incubated for $24 \mathrm{~h}$ at $37{ }^{\circ} \mathrm{C}$, with $5 \% \mathrm{CO}_{2}$ in a humidified atmosphere. The cells were then incubated with test compounds at various concentrations for various times. The reaction was stopped by removing the treatment media, adding MTT reagent $(0.1 \mathrm{mg} / \mathrm{mL})$, and then allowing the reagent to react at $37^{\circ} \mathrm{C}$ in $5 \% \mathrm{CO}_{2}$ for $2 \mathrm{~h}$. MTT was removed, and cells were lysed with DMSO. The absorbance at $570 \mathrm{~nm}$ was measured using an ELISA reader (PowerWave 340, Bio-Tek Instruments, Winooski, VT, USA). The cell viability (\%) was calculated using the following Equation:

$$
\text { Cell viability }(\%)=\left(\frac{T}{C}\right) \times 100
$$

where $\mathrm{T}$ is the absorbance in the test, and $\mathrm{C}$ is the absorbance for the control.

\subsection{Cell Cycle Analysis}

Cells were seeded in a 6-cm dish at $4 \times 10^{4}$ cells $/ \mathrm{mL}$ in $5 \mathrm{~mL}$ growth medium and incubated for $24 \mathrm{~h}$ at $37^{\circ} \mathrm{C}$, with $5 \% \mathrm{CO}_{2}$ in a humidified atmosphere. Afterwards, cells were pretreated with or without different fucoidans at a final concentration of $500 \mu \mathrm{g} / \mathrm{mL}$ for $6 \mathrm{~h}$, and then treated with or without 6-OHDA at a final concentration of $75 \mu \mathrm{M}$ for $24 \mathrm{~h}$. After treatment, the cells (including floating and adherent cells) were harvested and washed with $1 \times$ ice-cold phosphate-buffered saline (PBS) twice. The cell pellets were collected and fixed in 70\% ice-cold ethanol solution and stored in the freezer for at least $2 \mathrm{~h}$. After washing with staining buffer twice, cells were then resuspended in a solution containing $50 \mu \mathrm{g} / \mathrm{mL}$ PI and $25 \mu \mathrm{g} / \mathrm{mL}$ RNase A at $37^{\circ} \mathrm{C}$ for $15 \mathrm{~min}$. The stained cells were then transferred to flow tubes and the DNA contents in the cells were evaluated by a BD Accuri C6 flow cytometer (BD Biosciences, San Jose, CA, USA) and a minimum of 10,000 cells per sample was collected. The percentage of each phase in the cell cycle was determined by BD Accuri C6 software.

\subsection{Cytochrome c Release Analysis}

Cells were seeded in 6-cm dish at $4 \times 10^{4}$ cells $/ \mathrm{mL}$ in $5 \mathrm{~mL}$ growth medium and incubated for $24 \mathrm{~h}$ at $37^{\circ} \mathrm{C}$, with $5 \% \mathrm{CO}_{2}$ in a humidified atmosphere. Afterwards, cells were pretreated with or without different fucoidans at a final concentration of $500 \mu \mathrm{g} / \mathrm{mL}$ for $6 \mathrm{~h}$, and then treated with or without 6-OHDA at a final concentration of $75 \mu \mathrm{M}$ for $24 \mathrm{~h}$. After treatment, the cells (including floating and adherent cells) were harvested and washed with $1 \times$ ice-cold PBS twice. The cell pellets were collected, resuspended with $100 \mu \mathrm{L} 1 \times$ PBS, and $100 \mu \mathrm{L}$ fixation buffer was then added, followed by storage at $37^{\circ} \mathrm{C}$ for $20-60 \mathrm{~min}$ in the dark. Next the cells were washed with $2 \mathrm{~mL} 1 \times$ permeabilization buffer twice, and the cells were resuspended with $100 \mu \mathrm{L} 1 \times$ permeabilization buffer, followed by addition of $10 \mu \mathrm{L}$ FITC (fluorescein isothiocyanate)-labelled anti-cytochrome c antibody (Thermo Fisher Scientific, Waltham, MA, USA), and incubation at room temperature for $60 \mathrm{~min}$ in the dark. After washing with $2 \mathrm{~mL} 1 \times$ permeabilization buffer, the cells were centrifugated, and resuspended in $2 \mathrm{~mL}$ staining buffer. The stained cells were then transferred to flow tubes and analyzed by a BD Accuri C6 flow cytometer (BD Biosciences, San Jose, CA, USA) and a minimum of 10,000 cells per sample were collected. The results were calculated by BD Accuri C6 software. 


\subsection{Activated Caspase-8, -9 , and -3 Analyses}

The activation state of caspase-8, -9 and -3 was evaluated by using the CaspGLOW ${ }^{\mathrm{TM}}$ fluorescein active caspase staining kit (Thermo Fisher Scientific, Waltham, MA, USA). Briefly, cells were seeded in a 6-cm dish at $4 \times 10^{4}$ cells $/ \mathrm{mL}$ in $5 \mathrm{~mL}$ growth medium and incubated for $24 \mathrm{~h}$ at $37^{\circ} \mathrm{C}$, with $5 \% \mathrm{CO}_{2}$ in a humidified atmosphere. Afterwards, cells were pretreated with or without different fucoidans at a final concentration of $500 \mu \mathrm{g} / \mathrm{mL}$ for $6 \mathrm{~h}$, and then exposed to 6-OHDA at a final concentration of $75 \mu \mathrm{M}$ for $24 \mathrm{~h}$. After treatment, the cells (including floating and adherent cells) were harvested and washed with $1 \times$ ice-cold PBS twice. The cell pellets were collected and the cell density was adjusted to $1 \times 10^{6}$ cells $/ \mathrm{mL}$ with complete medium and then incubated with $1 \mu \mathrm{L}$ FITC-IETD-FMK (for caspase- 8 detection), FITC-LEHD-FMK (for caspase-9 detection), or FITC-DEVD-FMK (for caspase-3 detection) at $37^{\circ} \mathrm{C}$, with $5 \% \mathrm{CO}_{2}$ for $60 \mathrm{~min}$ in the dark. After washing with $0.5 \mathrm{~mL}$ wash buffer twice, the stained cells were transferred to flow tubes and analyzed by a BD Accuri C6 flow cytometer (BD Biosciences, San Jose, CA, USA) and a minimum of 10,000 cells per sample were collected. The data were calculated by BD Accuri C6 software.

\subsection{Quantitation of DNA Fragmentation by TUNEL Assay}

DNA fragmentation was evaluated using the Apo-BrdU apoptosis detection kit (Thermo Fisher Scientific, Waltham, MA, USA). Briefly, cells were seeded in a $6-\mathrm{cm}$ dish at $4 \times 10^{4}$ cells $/ \mathrm{mL}$ in $5 \mathrm{~mL}$ growth medium and incubated for $24 \mathrm{~h}$ at $37^{\circ} \mathrm{C}$, with $5 \% \mathrm{CO}_{2}$ in a humidified atmosphere. Afterwards, cells were pretreated with or without different fucoidans at a final concentration of $500 \mu \mathrm{g} / \mathrm{mL}$ for $6 \mathrm{~h}$, and then treated with or without 6-OHDA at a final concentration of $75 \mu \mathrm{M}$ for $24 \mathrm{~h}$. After treatment, the cells (including floating and adherent cells) were harvested and washed with $1 \times$ ice-cold PBS twice. The cell pellets were collected and fixed with $4 \%$ paraformaldehyde followed by $70 \%$ ice-cold ethanol and then stored in the freezer for at least $12 \mathrm{~h}$. After washing with $1 \mathrm{~mL}$ wash buffer twice, the fragmented DNA in apoptotic cells were labeled with BrdU followed by incubation with FITC-conjugated anti-BrdU antibody at room temperature for $30 \mathrm{~min}$ in the dark. The stained cells were then transferred to flow tubes and analyzed by a BD Accuri C6 flow cytometer (BD Biosciences, San Jose, CA, USA) and a minimum of 10,000 cells per sample were collected. The data were calculated by BD Accuri C6 software.

\subsection{Phosphorylated Akt Analysis}

Cells were seeded in a 6-cm dish at $4 \times 10^{4}$ cells $/ \mathrm{mL}$ in $5 \mathrm{~mL}$ growth medium and incubated for $24 \mathrm{~h}$ at $37^{\circ} \mathrm{C}$, with $5 \% \mathrm{CO}_{2}$ in a humidified atmosphere. Afterwards, cells were pretreated with or without different fucoidans at a final concentration of $500 \mu \mathrm{g} / \mathrm{mL}$ for $6 \mathrm{~h}$, and then treated with or without 6-OHDA at a final concentration of $75 \mu \mathrm{M}$ for $24 \mathrm{~h}$. After treatment, the cells (including floating and adherent cells) were harvested and washed with $1 \times$ ice-cold PBS twice. The cell pellets were collected, resuspended with $100 \mu \mathrm{L} 1 \times$ PBS, and $100 \mu \mathrm{L}$ fixation buffer was then added, followed by storage at $37^{\circ} \mathrm{C}$ for $20-60 \mathrm{~min}$ in the dark. Then $1 \mathrm{~mL} 90-100 \%$ ice-cold methanol was added and the cells were incubated at $2-8{ }^{\circ} \mathrm{C}$ for at least $30 \mathrm{~min}$. Next, the cells were washed with $5 \mathrm{~mL}$ staining buffer twice, resuspended with $100 \mu \mathrm{L}$ staining buffer, and $2 \mu \mathrm{L}$ APC (allophycocyanin)-conjugated anti-Akt1 antibody (Thermo Fisher Scientific, Waltham, MA, USA) and $5 \mu$ L FITC-conjugated anti-phospho-Akt (Ser473) antibody (Thermo Fisher Scientific, Waltham, MA, USA) were added, followed by incubation at room temperature for $60 \mathrm{~min}$ in the dark. After washing with $2 \mathrm{~mL} 1 \times$ staining buffer twice, the stained cells were transferred to flow tubes and analyzed by a BD Accuri C6 flow cytometer (BD Biosciences, San Jose, CA, USA) and a minimum of 10,000 cells per sample were collected. The results were determined by BD Accuri C6 software. 


\subsection{Statistical Analysis}

Results are presented as means \pm standard deviation (SD) of three independent experiments. Data were analyzed using the Statistical Package for the Social Sciences (SPSS). The results obtained were analyzed using one-way analysis of variance (ANOVA), followed by Duncan's Multiple Range tests. Data were considered statistically different at $p<0.05$.

\section{Conclusions}

In this paper, we extracted fucoidans from $\mathrm{SH}$ using $\mathrm{CPP}$ followed by hot water extraction. CPP increased the extraction yield, total sugar content, and molar ratios of sulfate/fucose of fucoidan, and decreased the molecular weight and impurities of fucoidan. All extracts (SH1-SH3) showed characteristics of fucoidan by compositional, FTIR spectroscopy, NMR spectroscopy, and molecular weight analyses. SH1-SH3 showed antioxidant activities by DPPH, ABTS, and FRAP analyses. Fucoidan extracts SH1-SH3 protected SH-SY5Y cells from 6-OHDA-induced apoptosis as illustrated by the cell cycle distribution, cytochrome c release, activation of caspase- $8,-9$, and -3 , and DNA fragmentation analyses. Among SH1-SH3, SH3 exhibited a relatively high extraction yield, the lowest levels of impurities, and was the most effective at reversing the neurotoxicity of SH-SY5Y cells induced by 6-OHDA. We therefore suggest that $\mathrm{SH} 3$ may be a good candidate for future development as a therapeutic agent for preventive therapy of neurodegenerative diseases, especially PD. We also demonstrated that phosphorylation of Akt is involved in the preventive effects of SH1-SH3 on 6-OHDA-induced neurotoxicity. Further elucidation of the molecular mechanism and the signaling cascade involved in the neuroprotective effects of SH1-SH3 (especially SH3) using differentiated SH-SY5Y cells or in vivo models is warranted.

Acknowledgments: This work was supported by a grant provided by the Ministry of Science and Technology (Grant No. MOST 106-2320-B-022-001), Taiwan, awarded to Chun-Yung Huang.

Author Contributions: Chun-Yung Huang and Po-Wei Chen conceived and designed the experiments; Chia-Hung Kuo and Po-Wei Chen performed the experiments; Chun-Yung Huang analyzed the data; Chun-Yung Huang contributed reagents/materials/analysis tools; and Chun-Yung Huang wrote the paper.

Conflicts of Interest: The authors declare no conflict of interest.

\section{References}

1. Reed, T.T. Lipid peroxidation and neurodegenerative disease. Free Radic. Biol. Med. 2011, 51, 1302-1319. [CrossRef] [PubMed]

2. Markesbery, W.R.; Carney, J.M. Oxidative alterations in Alzheimer's disease. Brain Pathol. 1999, 9, 133-146. [CrossRef] [PubMed]

3. Imbs, T.I.; Skriptsova, A.V.; Zvyagintseva, T.N. Antioxidant activity of fucose-containing sulfated polysaccharides obtained from Fucus evanescens by different extraction methods. J. Appl. Phycol. 2015, 27, 545-553. [CrossRef]

4. Ale, M.T.; Maruyama, H.; Tamauchi, H.; Mikkelsen, J.; Meyer, A.S. Fucoidan from Sargassum sp. and Fucus vesiculosus reduces cell viability of lung carcinoma and melanoma cells in vitro and activates natural killer cells in mice in vivo. Int. J. Biol. Macromol. 2011, 49, 331-336. [CrossRef] [PubMed]

5. Ale, M.T.; Mikkelsen, J.D.; Meyer, A.S. Important determinants for fucoidan bioactivity: A critical review of structure-function relations and extraction methods for fucose-containing sulfated polysaccharides from brown seaweeds. Mar. Drugs 2011, 9, 2106-2130. [CrossRef] [PubMed]

6. Huang, C.Y.; Wu, S.J.; Yang, W.N.; Kuan, A.W.; Chen, C.Y. Antioxidant activities of crude extracts of fucoidan extracted from Sargassum glaucescens by a compressional-puffing-hydrothermal extraction process. Food Chem. 2016, 197, 1121-1129. [CrossRef] [PubMed]

7. Yang, W.N.; Chen, P.W.; Huang, C.Y. Compositional characteristics and in vitro evaluations of antioxidant and neuroprotective properties of crude extracts of fucoidan prepared from compressional puffing-pretreated Sargassum crassifolium. Mar. Drugs 2017, 15, 183. [CrossRef] [PubMed] 
8. Chiang, P.S.; Lee, D.J.; Whiteley, C.G.; Huang, C.Y. Antioxidant phenolic compounds from Pinus morrisconicola using compressional-puffing pretreatment and water-ethanol extraction: Optimization of extraction parameters. J. Taiwan Inst. Chem. Eng. 2017, 70, 7-14. [CrossRef]

9. Chiang, P.S.; Lee, D.J.; Whiteley, C.G.; Huang, C.Y. Extracting antioxidant phenolic compounds from compressional-puffing pretreated Pinus morrisonicola: Effects of operational parameters, kinetics and characterization. J. Taiwan Inst. Chem. Eng. 2017, 75, 70-76. [CrossRef]

10. Sinha, S.; Astani, A.; Ghosh, T.; Schnitzler, P.; Ray, B. Polysaccharides from Sargassum tenerrimum: Structural features, chemical modification and anti-viral activity. Phytochemistry 2010, 71, 235-242. [CrossRef] [PubMed]

11. Li, B.; Lu, F.; Wei, X.J.; Zhao, R.X. Fucoidan: Structure and bioactivity. Molecules 2008, 13, 1671-1695. [CrossRef] [PubMed]

12. Hu, M.; Cui, N.; Bo, Z.X.; Xiang, F.X. Structural determinant and its underlying molecular mechanism of STPC2 related to anti-angiogenic activity. Mar. Drugs 2017, 15, 48. [CrossRef] [PubMed]

13. Wang, J.; Zhang, Q.B.; Zhang, Z.S.; Song, H.F.; Li, P.C. Potential antioxidant and anticoagulant capacity of low molecular weight fucoidan fractions extracted from Laminaria japonica. Int. J. Biol. Macromol. 2010, 46, 6-12. [CrossRef] [PubMed]

14. Movasaghi, Z.; Rehman, S.; ur Rehman, D.I. Fourier transform infrared (FTIR) spectroscopy of biological tissues. Appl. Spectrosc. Rev. 2008, 43, 134-179. [CrossRef]

15. Shao, P.; Pei, Y.P.; Fang, Z.X.; Sun, P.L. Effects of partial desulfation on antioxidant and inhibition of DLD cancer cell of Ulva fasciata polysaccharide. Int. J. Biol. Macromol. 2014, 65, 307-313. [CrossRef] [PubMed]

16. Palanisamy, S.; Vinosha, M.; Marudhupandi, T.; Rajasekar, P.; Prabhu, N.M. Isolation of fucoidan from Sargassum polycystum brown algae: Structural characterization, in vitro antioxidant and anticancer activity. Int. J. Biol. Macromol. 2017, 102, 405-412. [CrossRef] [PubMed]

17. Synytsya, A.; Bleha, R.; Synytsya, A.; Pohl, R.; Hayashi, K.; Yoshinaga, K.; Nakano, T.; Hayashi, T. Mekabu fucoidan: Structural complexity and defensive effects against avian influenza A viruses. Carbohydr. Polym. 2014, 111, 633-644. [CrossRef] [PubMed]

18. Bilan, M.I.; Grachev, A.A.; Shashkov, A.S.; Nifantiev, N.E.; Usov, A.I. Structure of a fucoidan from the brown seaweed Fucus serratus L. Carbohydr. Res. 2006, 341, 238-245. [CrossRef] [PubMed]

19. Tako, M.; Nakada, T.; Hongou, F. Chemical characterization of fucoidan from commercially cultured Nemacystus decipiens (Itomozuku). Biosci. Biotechnol. Biochem. 1999, 63, 1813-1815. [CrossRef] [PubMed]

20. Jégou, C.; Kervarec, N.; Cérantola, S.; Bihannic, I.; Stiger-Pouvreau, V. NMR use to quantify phlorotannins: The case of Cystoseira tamariscifolia, a phloroglucinol-producing brown macroalga in Brittany (France). Talanta 2015, 135, 1-6. [CrossRef] [PubMed]

21. Ermakova, S.; Sokolova, R.; Kim, S.M.; Um, B.H.; Isakov, V.; Zvyagintseva, T. Fucoidans from brown seaweeds Sargassum hornery, Eclonia cava, Costaria costata: Structural characteristics and anticancer activity. Appl. Biochem. Biotechnol. 2011, 164, 841-850. [CrossRef] [PubMed]

22. Lean, C.; Doran, S.; Somorjai, R.L.; Malycha, P.; Clarke, D.; Himmelreich, U.; Bourne, R.; Dolenko, B.; Nikulin, A.E.; Mountford, C. Determination of grade and receptor status from the primary breast lesion by magnetic resonance spectroscopy. Technol. Cancer Res. Treat. 2004, 3, 551-556. [CrossRef] [PubMed]

23. Mlynárik, V.; Cudalbu, C.; Xin, L.; Gruetter, R. ${ }^{1} \mathrm{H}$ NMR spectroscopy of rat brain in vivo at 14.1 Tesla: Improvements in quantification of the neurochemical profile. J. Magn. Reson. 2008, 194, 163-168. [CrossRef] [PubMed]

24. Bilan, M.I.; Grachev, A.A.; Ustuzhanina, N.E.; Shashkov, A.S.; Nifantiev, N.E.; Usov, A.I. A highly regular fraction of a fucoidan from the brown seaweed Fucus distichus L. Carbohydr. Res. 2004, 339, 511-517. [CrossRef] [PubMed]

25. Synytsya, A.; Kim, W.J.; Kim, S.M.; Pohl, R.; Synytsya, A.; Kvasnička, F.; Čopíková, J.; Park, Y. Structure and antitumour activity of fucoidan isolated from sporophyll of Korean brown seaweed Undaria pinnatifida. Carbohydr. Polym. 2010, 81, 41-48. [CrossRef]

26. Mandemakers, W.; Morais, V.A.; De Strooper, B. A cell biological perspective on mitochondrial dysfunction in Parkinson disease and other neurodegenerative diseases. J. Cell Sci. 2007, 120, 1707-1716. [CrossRef] [PubMed]

27. Gomez-Lazaro, M.; Bonekamp, N.A.; Galindo, M.F.; Jordán, J.; Schrader, M. 6-Hydroxydopamine (6-OHDA) induces Drp1-dependent mitochondrial fragmentation in SH-SY5Y cells. Free Radic. Biol. Med. 2008, 44, 1960-1969. [CrossRef] [PubMed] 
28. Lee, H.J.; Noh, Y.H.; Kim, Y.S.; Kim, K.Y.; Chung, Y.H.; Lee, W.B.; Kim, S.S. Baicalein attenuates 6-hydroxydopamine-induced neurotoxicity in SH-SY5Y cells. Eur. J. Cell Biol. 2005, 84, 897-905. [CrossRef] [PubMed]

29. Woodgate, A.; MacGibbon, G.; Walton, M.; Dragunow, M. The toxicity of 6-hydroxydopamine on PC12 and P19 cells. Mol. Brain Res. 1999, 69, 84-92. [CrossRef]

30. Bové, J.; Prou, D.; Perier, C.; Przedborski, S. Toxin-induced models of Parkinson's disease. NeuroRX 2005, 2, 484-494. [CrossRef] [PubMed]

31. Xicoy, H.; Wieringa, B.; Martens, G.J.M. The SH-SY5Y cell line in Parkinson's disease research: A systematic review. Mol. Neurodegener. 2017, 12, 10. [CrossRef] [PubMed]

32. Lopes, F.M.; Schröder, R.; da Frota Júnior, M.L.C.; Zanotto-Filho, A.; Müller, C.B.; Pires, A.S.; Meurer, R.T.; Colpo, G.D.; Gelain, D.P.; Kapczinski, F.; et al. Comparison between proliferative and neuron-like SH-SY5Y cells as an in vitro model for Parkinson disease studies. Brain Res. 2010, 1337, 85-94. [CrossRef] [PubMed]

33. Cheung, Y.T.; Lau, W.K.W.; Yu, M.S.; Lai, C.S.W.; Yeung, S.C.; So, K.F.; Chang, R.C.C. Effects of all-trans-retinoic acid on human SH-SY5Y neuroblastoma as in vitro model in neurotoxicity research. Neurotoxicology 2009, 30, 127-135. [CrossRef] [PubMed]

34. Jordán, J.; Galindo, M.F.; Tornero, D.; González-García, C.; Ceña, V. Bcl-XL blocks mitochondrial multiple conductance channel activation and inhibits 6-OHDA-induced death in SH-SY5Y cells. J. Neurochem. 2004, 89, 124-133. [CrossRef] [PubMed]

35. Wang, C.Y.; Wu, T.C.; Hsieh, S.L.; Tsai, Y.H.; Yeh, C.W.; Huang, C.Y. Antioxidant activity and growth inhibition of human colon cancer cells by crude and purified fucoidan preparations extracted from Sargassum cristaefolium. J. Food Drug Anal. 2015, 23, 766-777. [CrossRef] [PubMed]

36. Campos, C.B.; Paim, B.A.; Cosso, R.G.; Castilho, R.F.; Rottenberg, H.; Vercesi, A.E. Method for monitoring of mitochondrial cytochrome $\mathrm{c}$ release during cell death: Immunodetection of cytochrome $\mathrm{c}$ by flow cytometry after selective permeabilization of the plasma membrane. Cytom. A 2006, 69, 515-523. [CrossRef] [PubMed]

37. Fox, R.; Aubert, M. Flow cytometric detection of activated caspase-3. In Apoptosis and Cancer: Methods and Protocols, 2008th ed.; Mor, G., Alvero, A., Eds.; Humana Press Inc.: Totowa, NJ, USA, 2008; pp. 47-56.

38. Enari, M.; Sakahira, H.; Yokoyama, H.; Okawa, K. A caspase-activated DNase that degrades DNA during apoptosis, and its inhibitor ICAD. Nature 1998, 391, 43-50. [CrossRef] [PubMed]

39. Liu, X.S.; Li, P.; Widlak, P.; Zou, H.; Luo, X.; Garrard, W.T.; Wang, X.D. The 40-kDa subunit of DNA fragmentation factor induces DNA fragmentation and chromatin condensation during apoptosis. Proc. Natl. Acad. Sci. USA 1998, 95, 8461-8466. [CrossRef] [PubMed]

40. Yazdani, R.; Ganjalikhani-Hakemi, M.; Esmaeili, M.; Abolhassani, H.; Vaeli, S.; Rezaei, A.; Sharifi, Z.; Azizi, G.; Rezaei, N.; Aghamohammadi, A. Impaired Akt phosphorylation in B-cells of patients with common variable immunodeficiency. Clin. Immunol. 2017, 175, 124-132. [CrossRef] [PubMed]

41. Nakaso, K.; Ito, S.; Nakashima, K. Caffeine activates the PI3K/Akt pathway and prevents apoptotic cell death in a Parkinson's disease model of SH-SY5Y cells. Neurosci. Lett. 2008, 432, 146-150. [CrossRef] [PubMed]

42. Gibbons, M.N. The determination of methylpentoses. Analyst 1955, 80, 268-276. [CrossRef]

43. Filisetti-Cozzi, T.M.; Carpita, N.C. Measurement of uronic acids without interference from neutral sugars. Anal. Biochem. 1991, 197, 157-162. [CrossRef]

44. Honya, M.; Kinoshita, T.; Ishikawa, M.; Mori, H.; Nisizawa, K. Monthly determination of alginate, M/G ratio, mannitol, and minerals in cultivated Laminaria japonica. Bull. Jpn. Soc. Sci. Fish. 1993, 59, 295. [CrossRef]

45. Huang, C.Y.; Kuo, J.M.; Wu, S.J.; Tsai, H.T. Isolation and characterization of fish scale collagen from tilapia (Oreochromis sp.) by a novel extrusion-hydro-extraction process. Food Chem. 2016, 190, 997-1006. [CrossRef] [PubMed]

46. Benzie, I.F.F.; Strain, J.J. The ferric reducing ability of plasma (FRAP) as a measure of "Antioxidant power": The FRAP assay. Anal. Biochem. 1996, 239, 70-76. [CrossRef] [PubMed]

Sample Availability: Samples of the compounds are not available from the authors.

(C) 2017 by the authors. Licensee MDPI, Basel, Switzerland. This article is an open access article distributed under the terms and conditions of the Creative Commons Attribution (CC BY) license (http://creativecommons.org/licenses/by/4.0/). 